Review

\title{
Coupling Plant Biomass Derived from Phytoremediation of Potential Toxic-Metal-Polluted Soils to Bioenergy Production and High-Value by-Products-A Review
}

\author{
Vázquez-Núñez Edgar ${ }^{1, * \mathbb{D}}$, Fernández-Luqueño Fabián ${ }^{2} \mathbb{D}$, Peña-Castro Julián Mario ${ }^{3}$ and Vera-Reyes Ileana ${ }^{4} \mathbb{D}$ \\ 1 Departamento de Ingenierías Química, Electrónica y Biomédica, División de Ciencias e Ingenierías, \\ Campus León, Universidad de Guanajuato, Lomas del Bosque 103, Lomas del Campestre, \\ León, Guanajuato C.P. 37150, Mexico \\ 2 Programas en Sustentabilidad de los Recursos Naturales y Energía, Cinvestav Saltillo Industrial, \\ Parque Industrial, Ramos Arizpe, Coahuila C.P. 25900, Mexico; fabian.fernandez@cinvestav.edu.mx \\ 3 Laboratorio de Biotecnología Vegetal, Instituto de Biotecnología, Universidad del Papaloapan, \\ Tuxtepec, Oaxaca C.P. 68333, Mexico; julianpc@unpa.edu.mx \\ 4 Departamento de Biociencias y Agrotecnología, CONACYT-Centro de Investigación en Química Aplicada, \\ Blvd. Enrique Reyna Hermosillo 140, Saltillo, Coahuila C.P. 25294, Mexico; ileana.vera@ciqa.edu.mx \\ * Correspondence: edgar.vazquez@ugto.mx
}

check for updates

Citation: Edgar, V.-N.; Fabián, F.-L.; Mario, P.-C.J.; Ileana, V.-R. Coupling Plant Biomass Derived from

Phytoremediation of Potential Toxic-Metal-Polluted Soils to Bioenergy Production and High-Value by-Products-A Review. Appl. Sci. 2021, 11, 2982. https:// doi.org/10.3390/app11072982

Academic Editor: Bin Gao

Received: 24 February 2021

Accepted: 23 March 2021

Published: 26 March 2021

Publisher's Note: MDPI stays neutral with regard to jurisdictional claims in published maps and institutional affiliations.

Copyright: (c) 2021 by the authors. Licensee MDPI, Basel, Switzerland. This article is an open access article distributed under the terms and conditions of the Creative Commons Attribution (CC BY) license (https:// creativecommons.org/licenses/by/ $4.0 /)$.

\begin{abstract}
Phytoremediation is an attractive strategy for cleaning soils polluted with a wide spectrum of organic and inorganic toxic compounds. Among these pollutants, heavy metals have attracted global attention due to their negative effects on human health and terrestrial ecosystems. As a result of this, numerous studies have been carried out to elucidate the mechanisms involved in removal processes. These studies have employed many plant species that might be used for phytoremediation and the obtention of end bioproducts such as biofuels and biogas useful in combustion and heating. Phytotechnologies represent an attractive segment that is increasingly gaining attention worldwide due to their versatility, economic profitability, and environmental co-benefits such as erosion control and soil quality and functionality improvement. In this review, the process of valorizing biomass from phytoremediation is described; in addition, relevant experiments where polluted biomass is used as feedstock or bioenergy is produced via thermo- and biochemical conversion are analyzed. Besides, pretreatments of biomass to increase yields and treatments to control the transfer of metals to the environment are also mentioned. Finally, aspects related to the feasibility, benefits, risks, and gaps of converting toxic-metal-polluted biomass are discussed.
\end{abstract}

Keywords: phytoremediation; bioenergy; heavy metals; sustainability; by-products

\section{Introduction}

Human activities have generated enormous amounts of pollutants through diverse activities, for instance, agriculture, industrialization, and urbanization [1]. The variety of pollutants is diverse, from agrochemical compounds, nitrogen, and phosphorus to chemical wastes, halogenated compounds, potential toxic metals, radionuclides, plastics, and microplastics, among others, affecting air, water, and soil [2].

Heavy metals (HMs) are among the most abundant pollutants in soil [3]; these elements are well known for their potential toxicity, persistence, and bioaccumulative nature. Their natural source includes weathering of metal-bearing rocks and volcanic eruptions, while anthropogenic sources include mining and various industrial and agricultural activities [4].

These contaminants affect not only the environment but also interacting living organisms, i.e., plants, animals, and microorganisms [4]. Of special concern is the accumulation of toxic chemicals in edible plants or animals. Consequently, this accumulation transfers these compounds to humans or air and water via eutrophication, soil structure degradation, and altered microbial dynamics, affecting environmental quality productivity $[5,6]$. 
To overcome the concerns mentioned above, biotechnological strategies have been researched, i.e., bioaugmentation, biostimulation, and phytoremediation, which reduce the generation of by-products during the remotion of contaminants and enhance the complete mineralization of the pollutants. Besides, these biotechnologies reduce the cost of operation and maintenance $[7,8]$.

Phytoremediation uses plants to degrade or extract pollutants from an environment and is based on evolutionary traits developed by plants to deal with environmental challenges, especially ionic homeostasis in the rhizosphere and in plant cells [9].

The establishment of plants in contaminated soil produces ecological and economical benefits in many ways: (a) phytostabilization; (b) phytoextraction of precious metals like $\mathrm{Hg}, \mathrm{Ag}$, and Ni; (c) sustainable land management; and (d) improvement of soil utility and fertility $[10,11]$. Plant strategies in phytoremediation include phytofiltration, phytostabilization, phytoextraction, phytovolatilization, and phytodegradation. Table 1 summarizes the different techniques of soil phytoremediation.

Table 1. Biological strategies in phytoremediation processes.

\begin{tabular}{cccc}
\hline Strategy & Description & Reference \\
\hline $\begin{array}{c}\text { Phytostabilization } \\
\text { Phytoextraction }\end{array}$ & Restricting the mobility and, as a consequence, the bioavailability of pollutants in soil by plant roots & [12] \\
$\begin{array}{c}\text { Phytovolatilization } \\
\text { Phytodegradation }\end{array}$ & Accumulation on pollutants in harvestable biomass & Transformation of pollutants to volatile form and their release to the atmosphere & [14] \\
Rhizodegradation & Degradation of organic pollutants by the enzymatic plant machinery & [15] & [16] \\
\hline
\end{tabular}

The most important part of phytoremediation is the identification and establishment of metal-tolerant and metal accumulator plants. After that, different modifications and improvements are made until the creation of never-before-seen developments, such as the design and use of genetically modified plants [9] or the synthesis and use of nanomaterials to phytoremediate polluted sites $[17,18]$.

Phytoremediation has been used extensively around the world [9]; the benefits of this biotechnology are numerous regarding the simplicity of its application, the cost of application and maintenance, and the fact that it is considered friendly to the environment compared to other chemical or physical techniques. However, the economic feasibility of this technology can be limited by several factors, mainly time-consuming processes, contaminant specificity, limited metabolic-detoxifying capacity, extreme or variable climatological conditions, seasonal variability, and root-limiting growth [19]. In addition, the long-term act of phytoremediation increases the risk of incorporating toxic compounds into the trophic chain.

During recent decades, the integration of biomass (polluted or not) into energy production processes has been evaluated to increase economic and environmental benefits. This coupling can help remove the economic restrains of phytoremediation and decrease the remobilization of metals. The valorization of derived phytoproducts from phytoremediation residual biomass such as bioethanol, biodiesel, biogas, and heat would not only help satisfy the global energy demand but also provide an alternative for fostering a biobased economy for sustainable development [20]. Grzegórska et al. [21] published a review were crucial aspects related to the valorization of polluted biomass after harvesting were analyzed, i.e., bio-ore processing for metal recovery or the use of energy crops to produce bioenergy; however, more information about the development of strategies to manage the phytoremediation biomass in order to improve metal recovery to increase the biofuel yield and reduce the risk of the release of pollutants to the environment is still required.

Metal accumulator plants have attracted the interest of scientists, industry, environmentalists, decision makers, and engineers because the biomass produced during phytoremediation technologies can be detoxified and simultaneously can produce energy, extract high-value metallic elements, and shape sustainable development.

For these reasons, this review outlined the incorporation of biomass from potential toxic metal phytoremediation into bioenergy production processes and biomass pretreatments that increase biofuel yield and reduce the transfer of pollutants to the environment. 


\section{Management of Biomass from Phytoremediation Processes}

Since the early proposals of phytoremediation as an integrated environmental biotechnology, the fate of residual biomass posed a research challenge, especially the case of pollutants like toxic metals [22]. Initial ideas for processing were framed in traditional processes guided by decades-long experiences with radioactive waste, i.e., a concentration method and enclosed disposal. However, more elaborated methods like incineration techniques coupled with energy production and/or extraction of valuable metals (phytomining) were also contemplated in seminal works [23].

Although volume reduction by incineration and landfill dumping are still reported as the currently implemented disposal technologies [24], they are counterintuitive in terms of environmental remediation and pollutant containment. Thanks to decades-long research, these methods are starting to be challenged by technologies in the process of consolidation that accommodate circular economy approaches [25]. The new alternatives can be classified as composting, phytomining, and thermal treatments [26,27]. None of these are mutually exclusive and can be combined to reach an optimal point. The valorization of biomass into products with high added value can be divided into thermochemical and biochemical conversion. Chemical conversion mediated by heat is called thermochemical conversion and includes incineration, pyro-gasification, and pyrolysis [28]. When conversion is performed by microorganisms instead of heat, it is named biochemical conversion, e.g., anaerobic digestion or fermentation [29].

In this section is reviewed paradigmatic research that illustrates research trends in post-phytoremediation processing of plant biomass.

\subsection{Thermochemical Treatments}

Heavy metals are potentially toxic elements that cannot be degraded like organic pollutants. This conspicuous characteristic poses a great challenge for environmental engineers [30]. At a certain moment, the process has a dead-end mass transfer where the metal toxicity must be dealt with. In the past decade, several technologies have been tested to reduce the contaminated biomass by thermal processes and find a potential use of the process streams, including the recovery of the metal [31-33]. The latter has been traditionally regarded as a separate technology known as phytomining [34]. However, following the concept of closed-cycle processes, phytomining and energy recovery increasingly accompany thermal treatments.

The foundation of thermal treatments is the transformation of the organic fraction of the accumulator biomass under different thermochemical conversion processes into solids (e.g., ashes, biochar), liquids (e.g., oil), or gases (e.g., syngas, biogas) [31,35]. Simultaneously, the metal mass fraction must ideally be concentrated in a controlled and predictable way in one of these products. The metal partition in the different streams will determine the destiny of the product, and low concentrations may render it useful for further processing (compost material, catalyst material, or energy recovery), while high concentrations will limit downstream processing or must include another mass transfer operation to separate the metal fraction [36-38].

Then, the main constraint of any thermal process using this raw material is not only the partition of the metals between by-products but also its possible remobilization to the environment. Cui et al. [26] performed an extensive review of the available thermal technologies and concluded that the fate of metals responds to complex and multifactorial processes in all the available thermo-conversion formats.

Although there are no available predictive constants for any process, it has been observed through experimental testing that some metals like $\mathrm{Pb}$ or $\mathrm{Zn}$ have wide temperature ranges $\left(220-900{ }^{\circ} \mathrm{C}\right)$, where they can be largely $(>90 \%)$ captured in the solid phase [39,40]. On the other hand, other metals and metalloids like Cd [39] or As [41] are susceptible to leaving the system. This poses a risk in the process of using biomass to extract mixtures of metals.

To bypass this constraint, specialized products can also be obtained as secondary products of plant biomass processing. For example, by-products containing metals (e.g., Zn) 
have been conceptualized as catalytic materials that can be upgraded-through upstream processes - to obtain acetate/furan [40]. The solid by-products can be refunctionalized as metal adsorbents after metal leaching, and the gas streams can be employed as syngas rich in hydrogen and methane [39]. Cd catalysts aimed for photodegradation of water pollutants down to permissible levels were prepared [42]. Xing et al. [43] provided an alternative use of metal-contaminated streams when they demonstrated that vegetal biochar can be transformed with plating wastewater into reusable $\mathrm{Cd}$-biochar acting as nano $\mathrm{Cd}$-S with photocatalytic activities and tested the concept in dye removal from water.

Plant biomass can also be connected to the modern concept of a biorefinery that has expanded through the years to accommodate basic biofuels up to several high-end chemicals [44]. Therefore, the connection of biorefineries with harvested plant material from phytoremediation is a plausible research pathway if the management of post-phytoremediation biomass is conceptualized as an intermediate step of a process and not a dead end. However, a detailed level of metal compartmentalization control is not currently adequate for biorefineries, since these installations are located near plantations of genetically selected species for a predictable biofuel yield [45]. Finally, phytoremediation could greatly benefit from the biological optimization level that the biofuel industry has achieved for bioethanol [46], bio-oil [47], or specialty products [44].

\subsection{Biochemical Conversion of Biomass}

The biochemical conversion, i.e., composting, is applied to reduce the level of organic matter in phytoremediation waste and concentrate the metal-enriched fraction via composting or digestion [48,49]. Its advantages are that it is a low-energy method, extensively used for the treatment of many agricultural wastes for centuries, and that it only liberates emissions of already captured carbon (closed cycle) [50]. Some disadvantages are the probable remobilization of metals by microbes that is well known to occur naturally through microbial action (notably $\mathrm{Hg}$; [51]) and the production of dead-end solid waste that still needs confinement and poses a risk of leaching metals.

These latter problems can be overridden by coupling biochemical conversion with thermal treatment; nonetheless, the carbon lost during composting must be considered as energy loss for the upstream process. Another alternative is the composting and recovery of biogas from post-phytoremediation material. Interestingly, the plant-species-specific characterization indicates that not all plants are equally optimal for this process, since differences in accumulation and biodegradability affect the biogas yield and the final metal concentrations under normative limits [52].

Plant compost can also be used in a virtuous cycle to limit $\mathrm{Hg}$ leaching and increase fixation during phytoremediation in plant aerial parts [53], potentially setting a base to study $\mathrm{Hg}$ phytoextraction. It has been observed that $\mathrm{Cd}$ is easily removed from the plant material and efficiently phytoextracted even during repetitive harvesting using tobacco plants [54]; the leached biomass can find further safe uses like composting or bioenergy recovery.

Composting should not be discarded a priori based on its apparent simplicity; it has a valuable and potential use in cases where the metal concentration in the final compost is below normative standards for traditional sludge, therefore becoming fertilizers of the same phytoremediation site [27]. In this regard, Kidd et al. [55] reviewed the extensive agronomic experience of phytoremediation to manage the metal concentration in aerial tissue with periodical harvests and soil amendments. In this way, limiting the plant uptake and extending the remediation time can be counterbalanced by implementing up-stream operations, i.e., composting, that diversify the local bioenergy production economy.

\subsection{Phytomining}

Besides the treatments mentioned above, where the main objective is converting biomass into energy or functional materials, phytomining is a technology focused on the recovery of valuable metals from plant biomass [56]. 
Metals are released to the environment because of their exploitation as raw materials in modern industries such as batteries and electrochemistry. Therefore, it is a paradox that they end their life cycle as soil pollutants. Phytomining is a technology that aims to close this cycle by recovering the metals.

The fundamental base is leaching the contaminated plant biomass with acids to recover the adsorbed metal and to obtain biomass with metal concentrations in the range of environmental norms. Wang et al. [57] combined this concept and found that acid treatments improved plant biomass to adsorb more metals and can be further used to prepare biochar by pyrolysis aimed to confine metals.

Recently, the phytomining of palladium was tested with a model and well-known phytoremediator species, and recovery from synthetic tailings proved close to commercial ranges [58] and with high potential of improvement by chemical and biological engineering strategies. Potential plant species, soil amendments, and biomass processing have been tested for $\mathrm{Hg}$ and $\mathrm{Cd}[53,54]$.

Serpentine soil, famous for being the type of site where metal-tolerant plants have an important ecological niche, may be a rich source of metals, particularly Ni [59]. Plant screenings, agronomical practices, leaching methods, and full-scale yields have been tested in this commercially attractive environment [60]. Phytomining perspectives have also benefited from cell-level detailed determination of metal accumulation. Do Nascimento et al. [61] recently determined that citric acid treatment increases the potential of Odontarrhena to mine $\mathrm{Ni}$ and $\mathrm{Co}$ from serpentine soil and imaged how $\mathrm{Mn}, \mathrm{Ni}$, and $\mathrm{Co}$ are accumulated in different leaf cells. This work provided information about the technological feasibility of phytomining and paves the way to tailor accumulation patterns through genetic screening and testing.

The concept of differential compartmentalization already occurs in natural cultivars of sunflowers. Kolbas et al. [62] observed that Cu-contaminated soil could be employed to grow sunflowers, where $\mathrm{Cu}$ could be phytoextracted in leaves, and oil may be used as biofuel. Interestingly, the authors also suggested that plant biomass could be composted as a $\mathrm{Cu}$ fertilizer specialty. Another alternative for sunflower biomass used for phytoremediation is its use as raw material for industrial saccharification intended for bioethanol production [63]. Since modern saccharification is an enzymatic process, one concern was that metals in the biomass would inhibit the process. The authors observed that $\mathrm{Pb}$ was a strong inhibitor; $\mathrm{Cu}$ and $\mathrm{Cd}$ were intermediate; and $\mathrm{Ni}, \mathrm{As}$, and $\mathrm{Zn}$ did not inhibit the process. The presence of metals in biomass can also change the yield of the by-products. Doroshenko et al. [64] showed that it is the presence of a metal and the in vivo interactions that alter the carbon partition. As reviewed by Fagnano et al. [65], the metal concentration in shoot biomass can be controlled in desired ranges by agronomical practices or genetic screening of metal accumulator plants.

Finally, all treatment options for phytoremediation biomass will obtain more design options from the study of plant genetics. Recently, Basharat et al. [66] concluded by means of a literature review that many biological processes in phytoremediation have enough biological knowledge to either develop protocols or start testing modern genetic editing technologies like the clustered regularly interspaced short palindromic repeats (CRISPR)Cas9 nuclease system. Concomitantly, a vast array of biological discoveries ranging from small chelating molecules to transcription factors has been put in the context of its potential of genetic improvement $[9,67]$. This biological knowledge may be coupled with the abovereviewed engineering strategies to control the amount of metals and compartmentalization in the harvested biomass of phytoremediation sites to satisfy tailored processes that not only conform with legal limits but also push the current limits of our knowledge of the management of post-phytoremediation biomass.

In Table 2 are described experiments where metal-polluted biomass is treated under different strategies to develop feasible management strategies. 
Table 2. Studies focused on the development of strategies to manage biomass phytoremediation.

\begin{tabular}{|c|c|c|c|c|c|c|c|}
\hline Strategy & Products & Metal(s) & Concentration of Metal * & Experimental Conditions & Aim of the Study & Findings & Reference \\
\hline \multicolumn{8}{|l|}{ Thermochemical treatment } \\
\hline $\begin{array}{l}\text { Syngas and biochar } \\
\text { production by gasification } \\
\text { of Sedum alfredii }\end{array}$ & Syngas and biochar & $\begin{array}{l}\mathrm{Zn} \\
\mathrm{Pb}\end{array}$ & $\begin{array}{c}15,853 \mathrm{mg} / \mathrm{kg} \\
19 \mathrm{mg} / \mathrm{kg}\end{array}$ & $\begin{array}{l}\text { The gasification experiments were } \\
\text { conducted at heat treatment } \\
\text { temperatures }(\mathrm{HTTs}) \text { from } 300 \text { to } \\
900{ }^{\circ} \mathrm{C} \text { in } 100{ }^{\circ} \mathrm{C} \text { increments with } \\
\text { different gasifying agents }\left(\mathrm{N}_{2}, \mathrm{CO}_{2} \text {, }\right. \\
\text { and air). The HTT was divided into } \\
\text { the following three stages: low HTT } \\
\left(300{ }^{\circ} \mathrm{C} \text { and } 400^{\circ} \mathrm{C}\right) \text {, mid HTT }\left(500{ }^{\circ} \mathrm{C}\right. \\
\left.\text { and } 6000^{\circ} \mathrm{C}\right) \text {, and high HTT } \\
\left(700-900^{\circ} \mathrm{C}\right) .\end{array}$ & $\begin{array}{c}\text { To investigate the transfer } \\
\text { behavior of } \mathrm{Zn}, \mathrm{Cd} \text {, and } \mathrm{Pb} \\
\text { in syngas and biochar after } \\
\text { gasification of } S \text {. alfredii } \\
\text { performed at different } \\
\text { temperature series } \\
\left(300-900^{\circ} \mathrm{C}\right) \text { and different } \\
\text { gasifying agents }\left(\mathrm{NO}_{2},\right. \\
\mathrm{CO}_{2} \text {, and air) }\end{array}$ & $\begin{array}{l}\text { The high gasification } \\
\text { temperatures and a reducing } \\
\text { atmosphere enhanced the } \\
\text { volatilization of the metals. The } \\
\mathrm{CO}_{2} \text {-derived biochar had } \\
\text { moderate pH and showed } \\
\text { stability; the } \mathrm{N}_{2} \text {-derived biochar } \\
\text { showed better energy density. }\end{array}$ & [39] \\
\hline $\begin{array}{l}\text { Recycling of wastes of the } \\
\text { Zn accumulator Sedum } \\
\text { plumbizincicola via } \\
\text { subcritical hydrothermal } \\
\text { liquefaction (THL) }\end{array}$ & $\begin{array}{l}\text { Hydrochar, bio-oil, and } \\
\text { carboxylic acids }\end{array}$ & $\mathrm{Zn}$ & $1558 \mathrm{mg} / \mathrm{kg}$ & $\begin{array}{l}\text { The evaluated temperature reaction } \\
\text { ranged between } 190 \text { and } 310^{\circ} \mathrm{C} \text { for } 2 \mathrm{~h} \\
\text { at } 180 \mathrm{rpm} .\end{array}$ & $\begin{array}{l}\text { To investigate the } \\
\text { feasibility of recycling } \\
\text { toxic-metal-accumulated } \\
\text { biomass (S. plumbizicicola) } \\
\text { into small-molecule } \\
\text { chemicals and hydrochar } \\
\text { using a subcritical } \\
\text { THL reaction }\end{array}$ & $\begin{array}{l}\text { Approximately } 90 \% \text { of } \mathrm{Zn} \text { was } \\
\text { released from S. plumbizincicola } \\
\text { during THL at } 200^{\circ} \mathrm{C} \text {. The } \\
\text { low-Zn hydrochar was upgraded } \\
\text { into porous carbon with high } \\
\text { porosity and excellent } \mathrm{CO}_{2} \\
\text { capture. The results showed that } \\
\text { the release of } \mathrm{Zn} \mathrm{n}^{2+} \text { could promote } \\
\text { the production of acetic acid. }\end{array}$ & [40] \\
\hline $\begin{array}{l}\text { Combustion of } \\
\text { contaminated biomass } \\
\text { from phytoremediation } \\
\text { (Pteris vittata L.) }\end{array}$ & Flue gas & As & $486 \mathrm{mg} / \mathrm{kg}$ & $\begin{array}{l}\text { The temperature increased from } \\
\text { ambient temperature }\left(30^{\circ} \mathrm{C}\right) \text { to } 800^{\circ} \mathrm{C} \\
\text { at a heating rate of } 25^{\circ} \mathrm{C} / \mathrm{min} \text {. Air was } \\
\text { used as the carrier gas for tests, with } \\
\text { the gas flow rate maintained } \\
\text { at } 20 \mathrm{~mL} / \mathrm{min} \text {. }\end{array}$ & $\begin{array}{l}\text { To evaluate the injection of } \\
\text { sorbents during the } \\
\text { combustion of } \\
\text { phytoremediation biomass }\end{array}$ & $\begin{array}{l}\mathrm{CaO} \text { addition notably reduced the } \\
\mathrm{As} \text { in flue gas, and absorption was } \\
\text { efficient when } \mathrm{CaO} \text { was mixed } \\
\text { with biomass at } 10 \% \text { of } \\
\text { the total weight. }\end{array}$ & [41] \\
\hline $\begin{array}{l}\text { Pyrolysis carbonization } \\
\text { and the hydrothermal } \\
\text { reaction of the biomass of } \\
\text { the Cd-enriched } \\
\text { accumulator Sedum } \\
\text { plumbizincicola }\end{array}$ & $\begin{array}{l}\text { Mesoporous } \\
\text { carbo-supported nano CdS } \\
\text { (CdS@C) photocatalyst }\end{array}$ & $\mathrm{Cd}$ & In leaves: $>9000 \mathrm{mg} / \mathrm{kg}$ & $\begin{array}{l}\text { The samples were carbonized at } \\
700^{\circ} \mathrm{C} \text { for } 3 \mathrm{~h} \text { under a } \mathrm{N}_{2} \text { atmosphere } \\
\text { to obtain } \mathrm{S} \text {. plumbizincicola biochar } \\
\text { (SPC), followed by calcination at } 650 \\
{ }^{\circ} \mathrm{C} \text { for } 0.5 \mathrm{~h} \text { under a } \mathrm{N}_{2} / \mathrm{O}_{2}(6 / 1, \mathrm{v} / \mathrm{v}) \\
\text { atmosphere to obtain the Cd-enriched } \\
\mathrm{SPC}(\mathrm{C} \text {-SPC). The product was } \\
\text { washed with deionized water and } \\
\text { dried at } 50^{\circ} \mathrm{C} \text {, and the } \mathrm{Cd}-\mathrm{SPC} \text { was } \\
\text { mixed with } 5 \mathrm{mM} \mathrm{Na} \mathrm{N}_{2} \mathrm{~S} \text { solution, } \\
\text { heated at } 180^{\circ} \mathrm{C} \text { for } 24 \mathrm{~h} \text {, and then } \\
\text { cooled to ambient temperature. }\end{array}$ & $\begin{array}{c}\text { To provide new } \\
\text { information about } \\
\text { addressing the disposal } \\
\text { of Cd-enriched } \\
\text { hyperaccumulator biomass } \\
\text { by developing a catalyst } \\
\text { using a low-cost approach }\end{array}$ & $\begin{array}{l}\text { A CdS@C nanocomposite was } \\
\text { synthesized by in situ upcycling } \\
\text { of Cd-enriched S. plumbizincicola } \\
\text { biomass to solve the disposal and } \\
\text { recycling problem of } \\
\text { phytoextraction wastes. }\end{array}$ & [42] \\
\hline $\begin{array}{l}\text { Biochar produced from } \\
\text { rice straw by pyrolysis } \\
\text { carbonization and the } \\
\text { hydrothermal reaction } \\
\text { used to adsorb Cd from } \\
\text { plating wastewater }\end{array}$ & $\begin{array}{l}\text { Mesoporous } \\
\text { carbo-supported nano CdS } \\
\text { (CdS@C) photocatalyst }\end{array}$ & $\begin{array}{l}\text { Cd-enriched } \\
\text { biochar }\end{array}$ & $6.3 \%(w / w)$ & $\begin{array}{l}\text { The rice straw was dried for } 12 \mathrm{~h} \text { in an } \\
\text { oven at } 105^{\circ} \mathrm{C} \text {, and then the sample } \\
\text { was carbonized in a furnace at } 700{ }^{\circ} \mathrm{C} \\
\text { under a N atmosphere for } 3 \mathrm{~h} \text { to } \\
\text { obtained biochar capable of adsorbing } \\
\mathrm{Cd} \text {. The biochar was added to a } \\
\text { solution Cd-containing plating } \\
\text { wastewater and stirred for } 40 \mathrm{~min} \text {. } \\
\text { After adsorption, the Cd-enriched } \\
\text { biochar was washed and filtered. }\end{array}$ & $\begin{array}{l}\text { To develop a facile and } \\
\text { low-cost method for the } \\
\text { preparation of CdS@C } \\
\text { photocatalyst and recycle } \\
\text { Cd-enriched biochar after } \\
\text { treatment of Cd-containing } \\
\text { plating wastewater }\end{array}$ & $\begin{array}{c}\text { CdS@C nanocomposites } \\
\text { displayed enhanced } \\
\text { photocatalytic efficiency toward } \\
\text { the degradation of organic dyes. }\end{array}$ & [43] \\
\hline
\end{tabular}


Table 2. Cont

\begin{tabular}{|c|c|c|c|c|c|c|c|}
\hline Strategy & Products & Metal(s) & Concentration of Metal * & Experimental Conditions & Aim of the Study & Findings & Reference \\
\hline $\begin{array}{l}\text { Integration of ketone } \\
\text { synthons from biomass via } \\
\text { self-/cross-condensation }\end{array}$ & New class of biolubricants & & & & $\begin{array}{l}\text { To develop a method for } \\
\text { selectively upgrading } \\
\text { biomass-derived alkyl } \\
\text { methyl ketones into } \\
\text { trimer condensates }\end{array}$ & $\begin{array}{l}\text { It was shown that a range of cyclic } \\
\text { alkanes with desired composition, } \\
\text { exceptional cold-flow properties, } \\
\text { higher volumetric energy density, } \\
\text { and appropriate boiling } \\
\text { distributions can be produced for } \\
\text { jet fuel applications. }\end{array}$ & [44] \\
\hline \multicolumn{8}{|l|}{ Biochemical conversion } \\
\hline $\begin{array}{l}\text { Addition of amendments } \\
\text { (pine cone biochar } \\
\text { pyrolyzed at } 200^{\circ} \mathrm{C} \text { or } \\
500^{\circ} \mathrm{C} \text { ) to stabilize } \mathrm{Hg} \text { in } \\
\text { solutions of soil }\end{array}$ & & $\mathrm{Hg}$ & In soil: $41 \mathrm{mg} / \mathrm{kg}$ & $\begin{array}{l}\text { The redox conditions impacting } \\
\text { immobilization of Hg, methylmercury } \\
\text { (MeHg), and ethylmercury (EtHg) } \\
\text { were determined using an automated } \\
\text { biogeochemical microcosm system. } \\
\text { Nine redox windows were used, } \\
\text { covering the range between } \\
\sim-150 \text { and } 300 \mathrm{mV} \text {. }\end{array}$ & $\begin{array}{l}\text { To determine the } \\
\text { relationship between shifts } \\
\text { in Hg species and } \\
\text { alteration in the microbial } \\
\text { community structure and } \\
\text { quantify the efficiency of } \\
\text { biochar as an immobilizing } \\
\text { agent to reduce the } \\
\text { concentration of } \mathrm{Hg} \text {, } \\
\mathrm{MeHg} \text {, and EtHg } \\
\text { in soil solution }\end{array}$ & $\begin{array}{l}\text { Little influence was found on total } \\
\text { Hg release, methylation, and } \\
\text { ethylation; the crucial role of } \\
\text { sulfate-reducing bacteria as } \\
\text { methylators was also suggested. }\end{array}$ & [51] \\
\hline $\begin{array}{l}\text { Study of the treatability of } \\
\text { toxic-metal-polluted } \\
\text { biomass (Silybum } \\
\text { marianum, Piptatherum } \\
\text { miliaceum, Nicotiana glauca, } \\
\text { and Helianthus annuus) }\end{array}$ & $\begin{array}{c}\text { Biogas } \\
\text { Compost }\end{array}$ & $\begin{array}{l}\mathrm{Cu}: \\
\mathrm{Pb}: \\
\mathrm{Zn}: \\
\text { As: } \\
\mathrm{Fe}:\end{array}$ & $\begin{array}{l}230 \mu \mathrm{g} / \mathrm{g} \\
19,129 \mu \mathrm{g} / \mathrm{g} \\
2257 \mu \mathrm{g} / \mathrm{g} \\
1976 \mu \mathrm{g} / \mathrm{g} \\
215 \mathrm{mg} / \mathrm{g}\end{array}$ & & $\begin{array}{l}\text { To evaluate the potential } \\
\text { use of plant biomass from } \\
\text { phytostabilization of trace- } \\
\text { element-contaminated soil } \\
\text { for compost gas or thermal } \\
\text { energy production }\end{array}$ & $\begin{array}{l}\text { The results demonstrated that the } \\
\text { evaluated species can be easily } \\
\text { degraded by aerobic and } \\
\text { anaerobic processes, composting } \\
\text { and biogas production being } \\
\text { suitable recycling options. }\end{array}$ & [52] \\
\hline $\begin{array}{l}\text { Use of commercial } \\
\text { compost from municipal } \\
\text { green wastes to enhance } \\
\text { the phytoextraction of } \\
\text { mercury-contaminated soil } \\
\text { by Lepidium sativum L. }\end{array}$ & $\begin{array}{l}\text { Improvement of the } \mathrm{Hg} \\
\text { phytoextraction Compost } \\
\text { amendment facilitating the } \\
\text { translocation of pollutants } \\
\text { in soil }\end{array}$ & $\mathrm{Hg}$ & $\begin{array}{l}\text { In soil: } 10 \mathrm{mg} / \mathrm{kg} \\
\text { and } 100 \mathrm{mg} / \mathrm{kg}\end{array}$ & $\begin{array}{l}\text { Mercury(II) chloride }\left(\mathrm{HgCl}_{2}\right) \text { in } \\
\text { concentrations of } 10 \text { and } 100 \mathrm{mg} \mathrm{kg} \\
\text { soil dry weight was used } \\
\text { as a contaminant. } \\
\text { Phytoextraction experiments were set } \\
\text { up in plastic pots with a day } / \text { night } \\
\text { system of } 22 / 19^{\circ} \mathrm{C} \text { and } \\
\text { a photoperiod of } 14 \mathrm{~h} \text {. } \\
\text { The experiments were conducted } \\
\text { under greenhouse conditions. }\end{array}$ & $\begin{array}{l}\text { To determine the efficiency } \\
\text { of municipal green waste } \\
\text { compost application on the } \\
\text { Hg phytoextraction } \\
\text { process by L. sativum L. }\end{array}$ & $\begin{array}{l}\text { The compost application } \\
\text { increased both the accumulation } \\
\text { by the whole plant and the } \\
\text { translocation of Hg to shoots, } \\
\text { reducing the leaching of the metal } \\
\text { in soil. }\end{array}$ & [53] \\
\hline \multicolumn{8}{|l|}{ Phytomining } \\
\hline $\begin{array}{l}\text { Use of a novel } \\
\text { biosorption-pyrolysis } \\
\text { process using phosphoric } \\
\text { acid (PA) pretreatment of } \\
\text { biomass to attempt to } \\
\text { remove Pb from aqueous } \\
\text { solution and subsequently } \\
\text { immobilize the metal in } \\
\text { the char }\end{array}$ & $\begin{array}{l}\text { Char with }>95 \% \text { of } \mathrm{Pb} \\
\text { adsorbed by the } \\
\text { PA-pretreated biomass }\end{array}$ & $\mathrm{Pb}$ & $5,10,20,30,40,50 \mathrm{mg} / \mathrm{L}$ & $\begin{array}{l}\text { The biomass was mixed with } \mathrm{Pb} \\
\text { solutions and stirred for } 6 \mathrm{~h} \text {. } \\
\text { Pyrolysis of the Pb-contaminated } \\
\text { biomass was carried out at } 350 \text { or } \\
450^{\circ} \mathrm{C} \text { in a quartz tube furnace filled } \\
\text { with } \mathrm{N}_{2} \text { gas. }\end{array}$ & $\begin{array}{l}\text { To propose an alternative } \\
\text { for disposing of } \\
\text { contaminated biomass by } \\
\text { using a } \\
\text { biosorption-pyrolysis } \\
\text { process featured by } \\
\text { pretreatment of biomass } \\
\text { with PA and immobilize } \\
\text { the Pb in char }\end{array}$ & $\begin{array}{l}\text { This novel process can be used for } \\
\text { efficient removal of } \mathrm{Pb} \text { from } \\
\text { aqueous solution and the } \\
\text { immobilization } \mathrm{Pb} \text { in the char, } \\
\text { when the Hydrocotyle biomass is } \\
\text { pretreated with phosphoric acid. } \\
\text { The acid pretreatment introduces } \\
\text { a more functional group in the } \\
\text { biomass and enhances the } \\
\text { removal efficiency of } \\
\mathrm{Pb} \text { by biosorption. }\end{array}$ & [57] \\
\hline
\end{tabular}


Table 2. Cont

\begin{tabular}{|c|c|c|c|c|c|c|c|}
\hline Strategy & Products & Metal(s) & Concentration of Metal * & Experimental Conditions & Aim of the Study & Findings & Reference \\
\hline $\begin{array}{l}\text { Arabidopsis plants grown } \\
\text { hydroponically and dosed } \\
\text { with Pd solutions to } \\
\text { determine Pd } \\
\text { concentrations in the } \\
\text { biomass to obtain } \\
\text { catalytic activity }\end{array}$ & $\begin{array}{l}\text { Active material } \\
\text { comparable to } \\
\text { commercially available } 3 \% \\
\text { carbon on palladium } \\
\text { obtained catalytically }\end{array}$ & $\mathrm{Pd}$ & $\begin{array}{l}0.5 \mathrm{mM} \text { to } 1 \mathrm{mM} \\
\text { of potassium } \\
\text { tetrachloropalladate }\end{array}$ & $\begin{array}{l}\text { The plants were grown in liquid } \\
\text { cultures. The trays were placed } \\
\text { in a greenhouse. } \\
\text { To test the catalytic activity, dried plant } \\
\text { material was pyrolyzed using a } \\
\text { furnace under } \mathrm{N}_{2} \text { at } 300^{\circ} \mathrm{C} \text {. }\end{array}$ & $\begin{array}{l}\text { To experimentally } \\
\text { determine the minimum } \\
\text { concentration of palladium } \\
\text { needed in dry plant } \\
\text { biomass to achieve } \\
\text { catalytic activity }\end{array}$ & $\begin{array}{l}\text { It was demonstrated that } \\
\text { Arabidopsis can take up and store } \\
\text { palladium as nanoparticles and } \\
\text { that the dried biomass has } \\
\text { catalytic activity comparable to } \\
\text { commercial catalysts. }\end{array}$ & [58] \\
\hline $\begin{array}{l}\text { Applying citric acid (CA) } \\
\text { to the soil in order to } \\
\text { increase phytomin- } \\
\text { ing/phytoremediation of } \\
\text { serpentine soil }\end{array}$ & $\begin{array}{l}\text { Biomass with a high } \\
\text { concentration of } \mathrm{Ni} \\
\text { accumulated in leaves } \\
\text { when applying CA in soil }\end{array}$ & $\mathrm{Ni}$ & $\begin{array}{l}\text { In leaves: } 1231 \mu \mathrm{gg} / \mathrm{g} \text { to } \\
1900 \mu \mathrm{g} / \mathrm{g}\end{array}$ & $\begin{array}{l}\text { The experiments were carried out in a } \\
\text { growth chamber under controlled } \\
\text { temperature and light conditions. The } \\
\text { photoperiod was } 12 / 12 \text { day } / \text { night, } \\
\text { and day /night temperatures were } \\
24^{\circ} \mathrm{C} / 18^{\circ} \mathrm{C} \text {, with a photosynthetic } \\
\text { photon flux density of } 600 \mu \mathrm{mol}^{-2} \mathrm{~S}^{-1} \text {. } \\
\text { For analysis of metal accumulation, } \\
\text { leaves were taken from each plant } \\
\text { seven days after chelator application } \\
\text { and rinsed with deionized water. } \\
\text { Leaves were then dried in an oven at } \\
75^{\circ} \mathrm{C} \text {, ground, and digested. The } \\
\text { metal concentration was determined } \\
\text { by inductively coupled plasma mass } \\
\text { spectrometry (ICP-MS). }\end{array}$ & $\begin{array}{l}\text { To investigate whether } \\
\text { Ni phytomining/ } \\
\text { phytoremediation using } \\
\text { Odontarrhena muralis can } \\
\text { benefit from applying citric } \\
\text { acid to serpentine soil } \\
\text { enriched with Ni }\end{array}$ & $\begin{array}{l}\text { Citric acid application to soil } \\
\text { increased the concentration of } \mathrm{Ni} \\
\text { in the leaves of O. muralis by } 55 \% \text {. }\end{array}$ & [61] \\
\hline $\begin{array}{l}\text { The addition of compost } \\
\text { and limestone to soils in } \\
\text { order to enhance the } \\
\text { phytoextraction and } \\
\text { oilseed production of } \\
\text { Helianthus annuus }\end{array}$ & $\begin{array}{l}\text { H. annuus can be used as a } \\
\text { phytoextractor in soils at } \\
800-1200 \mathrm{mg} \mathrm{Cu} / \mathrm{kg} \text { in } \\
\text { topsoil and to } \\
\text { produce oilseeds. }\end{array}$ & $\mathrm{Cu}$ & $\begin{array}{l}\text { In shoots: } 4.9-34.4 \mathrm{mg} / \mathrm{kg} \\
\text { In leaves: } 10-51 \mathrm{mg} / \mathrm{kg}\end{array}$ & $\begin{array}{l}\text { Plants were cultivated in soil under } \\
\text { environmental conditions at a density } \\
\text { of } 105,000 \text { plants } / \text { ha. The } 13 \text { th leaves } \\
\text { were collected, washed with distilled } \\
\text { water, and oven-dried }\left(50^{\circ} \mathrm{C}\right) \text {. All } \\
\text { plants were manually harvested, with } \\
\text { stems cut } 1 \mathrm{~cm} \text { above the soil. } \\
\text { Biomass was ground and wet-digested } \\
\text { under microwaves. } \\
\text { Mineral concentrations in digests were } \\
\text { determined by inductively coupled } \\
\text { plasma-atomic emission } \\
\text { spectroscopy (ICP-AES). }\end{array}$ & $\begin{array}{l}\text { To use Helianthus annuus } \\
\text { for Cu phytoextraction and } \\
\text { oilseed production on } \\
\text { Cu-contaminated soils } \\
\text { amended with compost or } \\
\text { dolomitic limestone }\end{array}$ & $\begin{array}{l}\text { The addition of compost and } \\
\text { dolomitic limestone reduced the } \\
\text { labile Cu pool in amended soils. } \\
\text { Most tested sunflower cultivars } \\
\text { experienced a decreased } \\
\text { in seed yield. }\end{array}$ & [62] \\
\hline $\begin{array}{l}\text { Use of microwave-assisted } \\
\text { pyrolysis of the } \\
\text { hyperaccumulators } \\
\text { Stackhousia tryonii and } \\
\text { Alyssum bertolonii }\end{array}$ & $\begin{array}{l}\text { High biochar yields and } \\
\text { more cellulose-derived } \\
\text { products }\end{array}$ & $\mathrm{Ni}$ & $\begin{array}{l}\text { S. tryonii } \\
0.93 \mathrm{wt} \% \\
\text { A. bertolonii } \\
0.35 \mathrm{wt} \%\end{array}$ & $\begin{array}{l}\text { Microwave-assisted pyrolysis was } \\
\text { conducted in dynamic power mode. } \\
\text { The target temperature was } 280^{\circ} \mathrm{C} \text {. } \\
\text { The extraction of bio-oil was carried } \\
\text { out using acetone, and it was } \\
\text { centrifuged, decanted, and filtered. } \\
\text { Gas chromatography-mass } \\
\text { spectrometry (GC-MS) and gas } \\
\text { chromatography-flame ionization } \\
\text { detection (GC-FID) were performed. }\end{array}$ & $\begin{array}{l}\text { To describe the effect of the } \\
\text { natural occurrence of } \\
\text { nickel in } \\
\text { hyperaccumulator plants } \\
\text { on the microwave } \\
\text { biomass pyrolysis }\end{array}$ & $\begin{array}{l}\text { An inhibitory effect of Ni was } \\
\text { observed on parts of the plant } \\
\text { biomass decomposition and } \\
\text { different distribution of } \\
\text { cellulose-derived chemical } \\
\text { products, representing an } \\
\text { exploitable opportunity } \\
\text { in a biorefinery. }\end{array}$ & [64] \\
\hline
\end{tabular}

* Based on dry matter of biomass. 


\section{Coupling Phytoremediation and Bioenergy Production}

The use of biomass to produce fuels is one of the most attractive solutions for the increasing world energy demand. The management of metal-polluted biomass after phytoremediation has been addressed by many authors, who have demonstrated enormous potential in incorporating phytoremediation biomass into bioenergy technology based on thermal, thermochemical, or biochemical processes [31,68,69].

Biomass can be converted into various forms of bioenergy such as liquid biofuels (bioethanol and biodiesel), heat, and gaseous fuels (methane or hydrogen) [70].

\subsection{Thermochemical Conversion of Contaminated Biomass: Combustion, Gasification, and Pyrolysis}

Biomass is the organic material composed of water, cellulose, hemicellulose, lignin, lipids, proteins, sugars, starch, and other compounds [71] and is potentially able to produce energy by thermal oxidation [72]. Some studies have reported that approximately $96 \%$ of the world's bioenergy is generated by biomass combustion [73].

The use of energy to oxidize residues such as biomass via gasification or combustion has a purpose to generate thermal energy and simultaneously destroy or recover possible toxic compounds under emission control [74]. There are two important sub-routes to recover energy from biomass: first, gasification that is relevant to produce $\mathrm{CO}$ and $\mathrm{H}_{2}$ for Fischer-Tropsch synthesis (conversion of hydrogen and carbon monoxide into hydrocarbon products) [75], and second, combustion, which is a method of burning biomass to generate hot gasses to be used in energy generation processes [76].

Gomes [77] mentioned that the biomass produced in phytoremediation could be economically valorized in the form of bioenergy, i.e., biogas, biofuels, and combustion, even when the incorporation of contaminants into the biomass represents a potential risk during the management of this cellulosic material [78]. This risk is mostly associated with the reincorporation of these pollutants into the soil, i.e., toxic heavy metals and metalloids, due to inappropriate management and disposal [79]; important efforts have been made in order to reduce this risk, and some solutions have been offered in terms of pretreatments of the biomass and new materials used as adsorbers.

In an experiment carried out by Aghaalikhani et al. [80], gasification products obtained in a bed-scale fluidized bed of hazelnut shells, simple poplar, and poplar coming from a phytoremediation procedure of soils polluted with different toxic metals such as $\mathrm{Cu}$, $\mathrm{Cd}, \mathrm{Ni}, \mathrm{Pb}, \mathrm{Zn}, \mathrm{Hg}$, As, Mn, and $\mathrm{Sr}$ were evaluated. The study concluded that hazelnut shells and poplar could be easily gasified in the equipment, producing a good-quality gas with low-polluting by-products. The poplar sample showed lower tar content and higher gas yield. It was proposed that $\mathrm{Ca}$ and $\mathrm{Mg}$ found in higher quantities in poplar samples could have a catalytic effect in tar reforming, thus producing a lower quantity of heavy hydrocarbons.

The particulate size of biomass is also an important factor in determining the effectiveness of combustion and pyrolysis. Mlonka-Mędrala et al. [81] evaluated two fractions of HMs contaminated biomass samples, i.e., small size $(<0.09 \mathrm{~mm})$ and large samples $(>0.425 \mathrm{~mm})$ of mixed cereal straw, Miscanthus $x$ giganteous and Salix viminalis. During pyrolysis, the gaseous products were analyzed with GC-MS, and it was observed that size influences the activation energy of combustion and pyrolysis of biomass samples. This report supports the idea that using a thermochemical process to reduce the waste volume and the recuperation of metals may be a sustainable technology, especially for metal-contaminated biomass [82].

As mentioned before, a potential risk linked to this phytotechnology is the reinsertion of the metals into the environment. For this reason, Han et al. [32] proposed using adsorption-pyrolysis technology to recover valuable metals in solution from biomass after phytoremediation of polluted soils. Broussonetia papyrifera biomass was collected and used to study the recovery of valuable metals from soil and water since it is tolerant to toxic metals and has a large biomass. The soil and water samples were taken from mining and 
smelting industrial areas, where the main metals found were $\mathrm{Cu}$ and $\mathrm{Cd}$. The biomass was exposed to soil and water samples to facilitate the adsorption of metals at 0 to $180 \mathrm{~min}$ of exposure, and three different $\mathrm{pH}$ values were tested, i.e., 2,4 , and 6 . After pyrolysis $\left(1000{ }^{\circ} \mathrm{C}\right)$, the concentration of metals was determined. The authors concluded that $B$. papyrifera biomass harvested from phytoremediation can be successfully used to recover HMs by adsorption-pyrolysis technology. In addition, it was observed that the $\mathrm{pH}$ value is crucial to increase the adsorptive value of biomass; at $\mathrm{pH}$ 6.0, they observed the highest sorption value for $\mathrm{Cu}$ and $\mathrm{Cd}(2.7 \mathrm{wt} \%$ and $1.25 \mathrm{wt} \%)$. The pyrolysis experiments demonstrated that the highest $\mathrm{pH}$ value promotes the yield of solid-phase products and the enrichment of the potentially toxic metals into the residues. Finally, at $\mathrm{pH} 6$ and a pyrolysis temperature of $450{ }^{\circ} \mathrm{C}$, the residue contained $7.13 \mathrm{wt} \%(\mathrm{Cd})$ and $6.58 \mathrm{wt} \%(\mathrm{Cu})$, which can be considered as bio-ore.

He et al. [83] reported the biomass characterization of Avicennia marina, a species distributed in tropical and subtropical coastal mangroves contaminated with metals and metalloids, and the pyrolytic products were studied. In this study, the effect of pyrolysis temperature on the properties of the polluted biomass contaminated with metals $\left(300-800^{\circ} \mathrm{C}\right.$ ) and on the subsequent pyrolytic products (biochar, bio-oil, and gas) was studied. The researchers concluded that the presence of metals in the biomass contributes to a significantly higher ash content, and it was also found that during pyrolysis, toxic metals in biomass increase the relative evolution of $\mathrm{CO}_{2}$ and $\mathrm{H}_{2}$ in volatiles, while slightly reducing the $\mathrm{CO}$ content.

Frequently, metals are not the only soil pollutant. For example, mangroves are environmentally affected by organic and inorganic contaminants such as oil spills and toxic metals runoff. For this reason, He et al. [83] employed Avicennia marina to study the removal of metals in these ecosystems and then evaluated the effect of temperature on the pyrolysis products of this biomass. It was reported that contaminated roots were exposed to land and sediments polluted with metals, such as $\mathrm{As}, \mathrm{Cr}, \mathrm{Ni}$, and $\mathrm{Pb}$. The biomass was preconditioned by drying and milling and tested with computer-aided thermal analysis (CATA) to calculate the specific heat of the biomass and thermogravimetric analysis (TGA) to determine the change in biomass samples during pyrolysis. The results demonstrated that slow pyrolysis might be an effective technology for converting metal-contaminated biomass into valuable products, remarking that the pyrolysis temperature is the main factor that regulates the physicochemical properties of the pyrolytic products. At the same time, the presence of metals in samples did not have a negative effect; on the contrary, the presence of these metals contributed significantly to higher biochar and pyrolytic gas yields, with a lower bio-oil yield at a temperature range of $300-800{ }^{\circ} \mathrm{C}$.

The implementation of pretreatments has been tested to increase the yield of pyrolysis technologies. For example, He et al. [84] pretreated metal-contaminated biomass of A. marinna with ferric salts $\left(\mathrm{FeCl}_{3}\right.$ and $\left.\mathrm{Fe}\left(\mathrm{NO}_{3}\right)_{3}\right)$ prior to pyrolysis $\left(300-700^{\circ} \mathrm{C}\right)$ to increase the yield of gases and reduce the bio-oil production. The results showed that the impregnated ferric salts increased the fixed carbon content of biochar, the hydrocarbon fraction in bio-oils, and the evolution of $\mathrm{CO}_{2}$ and $\mathrm{H}_{2}$. During pyrolysis, the ferric salts enhanced the recovery of metals, i.e., $\mathrm{As}, \mathrm{Cr}, \mathrm{Ni}$, and $\mathrm{Pb}$, in biochar and decreased their distribution in gases. Interestingly, the ferric salt pretreatment inhibited the mobility and bioavailability of most elements in the biochar. This study indicates that ferric salt impregnation catalyzes the pyrolysis process of metal-contaminated biomass, with minimal environmental risks. It provides a new process to optimize the phytoremediation-pyrolysis technology in a safe and value-added way.

In an innovative effort to contribute to the sustainability of the valorization of phytoremediation biomass, Zeng et al. [85] evaluated the performance of a solar reactor where metal-contaminated biomass was pyrolyzed. Willow wood (Salix spp.) adsorbed with $\mathrm{Cu}$ and $\mathrm{Ni}$ was pyrolyzed in the reactor under different temperatures $\left(600-1600{ }^{\circ} \mathrm{C}\right)$ and two different heating rates $\left(10\right.$ and $\left.50^{\circ} \mathrm{C} / \mathrm{s}\right)$. The results showed that a minimum threshold temperature of $1000^{\circ} \mathrm{C}$ was required in samples to promote $\mathrm{Cu}$ and Ni catalytic effects 
on cracking and reforming tar. This led to increased gas yields at $1200{ }^{\circ} \mathrm{C}$ by $14.7 \%$ and $34.4 \%$, respectively, compared with that from raw willow. In particular, $\mathrm{H}_{2}$ and $\mathrm{CO}$ production from Ni-impregnated willow was higher than that from raw willow (10.30 and $12.16 \mathrm{~mol} / \mathrm{kg}$ of wood versus 6.59 and $8.20 \mathrm{~mol} / \mathrm{kg}$ of wood) for fast pyrolysis $\left(50{ }^{\circ} \mathrm{C} / \mathrm{s}\right)$. Under a heating rate of $10{ }^{\circ} \mathrm{C} / \mathrm{s}$, only nickel-impregnated willow showed increased $\mathrm{H}_{2}$ and $\mathrm{CO}$ yields compared to raw willow. This study confirmed that the solar pyrolysis of phytoremediation biomass is a sustainable alternative to producing valuable syngas.

The disposal of large quantities of contaminated biomass via combustion is increasing [86,87], so it is important not only to provide the required energy, especially in poor and underserved areas, but also to know the mechanisms involved in the capture of contaminants in fluxes and avoid the release of toxic compounds to the environment. For these reasons, research on the disposal of phytoremediation biomass through combustion in low-income regions is important. For example, three Pteris vittata L. biomasses with different concentrations of As from three different regions in China were investigated [88]. The combustion results in pilot-scale trials showed that the As concentration in flue gas was greater than that allowed by national standards in the trial with no control, and the As concentration in biomass was $486 \mathrm{mg} / \mathrm{kg}$. Parallelly, for As chemical capture tests, $\mathrm{CaO}$ was blended with biomass as a chemical absorber at $5 \%, 10 \%$, and $15 \%$ of feedstock weight. The samples were pelletized and combusted. The results showed that the absorption of As was efficient when $\mathrm{CaO}$ was mixed with biomass. $\mathrm{CaO}$ addition notably reduced arsenic emission in flue gas, and absorption was efficient when $\mathrm{CaO}$ was mixed with biomass at $10 \% w / w$. For the trial with $10 \% \mathrm{CaO}$ addition, arsenic recovery from ash reached $76 \%$, which is an $\sim 8$-fold increase compared with the control. The authors concluded that this disposal technology is economically feasible in low-income areas and is environment friendly.

Many valuable by-products can be obtained from combustion biomass, which is why the use of the ashes to supplement soils as fertilizers has also been analyzed. Pogrzeba et al. [89] reported a study where the use of Sida hermaphrodita to phytoextract toxic metals from soils was carried out. The study consisted in planting $S$. hermaphrodita in soils where $\mathrm{Pb}, \mathrm{Cd}$, and $\mathrm{Zn}$ concentrations exceeded the limits sets by the Polish law for arable soils. Three treatments were established: plant growth in polluted soils without fertilizer (control), plant growth in polluted soils with standard fertilization (N, P, and K), and plant growth with a commercial microbial inoculum. The phytoextraction potential was determined, and the gasification experiment was carried out to determine the calorific value of the biomass. The authors reported that the phytoextraction of $S$. hermaphrodita depends on the bioavailable form of the metals in the soil and that fertilization can reduce the accumulation of metals in plants. Regarding calorific values, small differences in the low heating value (LHV) were found between biomass from phytoremediation compared to other non-contaminated biomasses from other reports, indicating that despite contamination, the material is suitable for energy production. Additionally, the authors suggested that ashes after incineration can be used as fertilizers in forestry and agriculture, especially in sites where phytoremediation technologies are carried out.

Increasing experimental conditions can help to determine the necessary biomass pretreatments to increase the product yield and reduce toxic by-products. Ancona et al. [90] proposed that it is necessary to assess the biomass quality to determine the gasification capabilities. To verify this hypothesis, the authors evaluated specific treatments of poplar biomass from phytoremediation processes of soils polluted with metals (Be, V, Cr, Co, Ni, As, Se, Cd, Sn, Sb, Tl, and Pb under detection limits; $\mathrm{Cu}$ and $\mathrm{Zn}$ above the limits) and polychlorinated biphenyl (PCB). This research demonstrated that contaminated biomass gasification from phytoremediation produces syngas similar to that from non-contaminated biomass. This conclusion is also supported by the fact that contaminant residues were concentrated mainly in roots and undetected in shots. Similarly, the study reported that the concentration of contaminants in the pruning was negligible; the amount of metals ranged from 0.01 to $0.70 \mathrm{mg} / \mathrm{kg}$, except for $\mathrm{Cu}$ and $\mathrm{Zn}(\sim 20 \mathrm{mg} / \mathrm{kg})$. It was remarked that 
a specific treatment for pollutant capture is necessary when the roots are sampled and used for the gasification process.

The above-reviewed examples indicate that the concept of linking phytoremediation and thermochemical biofuel production is a potential and promising pathway toward sustainability, valorizing the polluted biomass into metal-free biofuels and by-products, while allowing the recovery of HMs. Besides the benefits of producing bioenergy from polluted biomass, the generation of potentially toxic streams must be minimized [91,92], which has focused the investigation of sorbents, demineralization, and leaching techniques in order to remove or immobilize HMs.

Table 3 summarizes experiments related to the analysis of phytoremediation biomass as feedstock in thermochemical processes, including determination of calorimetric values of biomass, the effectiveness of pretreatments to improve the quality and yield of products, and improvement of conversion technologies. 
Table 3. Studies related to the use of phytoremediation biomass as feedstock in thermochemical processes.

\begin{tabular}{|c|c|c|c|c|c|c|}
\hline Plant Species & Family & Metal(s) & Concentration of Metal ${ }^{*}$ & Process & Aim of the Study & Reference \\
\hline \multirow{7}{*}{ Avicennia marina } & \multirow{7}{*}{ Acanthaceae } & $\mathrm{Cr}$ & $1.20 \mathrm{mg} / \mathrm{kg}$ & \multirow{7}{*}{ Pyrolysis } & \multirow{7}{*}{$\begin{array}{l}\text { Slow pyrolysis of } A \text {. marina impregnated with metals } \\
\text { to determine their effect on the production of } \\
\text { biochar, bio-oil, and pyrolytic gas. }\end{array}$} & \multirow{7}{*}{ [93] } \\
\hline & & $\mathrm{Mn}$ & $93.99 \mathrm{mg} / \mathrm{kg}$ & & & \\
\hline & & Co & $1.25 \mathrm{mg} / \mathrm{kg}$ & & & \\
\hline & & $\mathrm{Fe}$ & $863.2 \mathrm{mg} / \mathrm{kg}$ & & & \\
\hline & & $\mathrm{Cu}$ & $19.63 \mathrm{mg} / \mathrm{kg}$ & & & \\
\hline & & $\mathrm{Zn}$ & $108.7 \mathrm{mg} / \mathrm{kg}$ & & & \\
\hline & & $\mathrm{Cd}$ & $0.457 \mathrm{mg} / \mathrm{kg}$ & & & \\
\hline $\begin{array}{l}\text { Sida hermaphrodita } \\
\text { Miscanthus } x \text { giganteus } \\
\text { Spartina pectinata } \\
\text { Panicum virgatum }\end{array}$ & $\begin{array}{l}\text { Malvaceae } \\
\text { Poaceae } \\
\text { Poaceae } \\
\text { Poaceae }\end{array}$ & $\begin{array}{l}\mathrm{Pb} \\
\mathrm{Zn} \\
\mathrm{Cd}\end{array}$ & $\begin{array}{l}>18 \mathrm{mg} / \mathrm{kg} \\
>30 \mathrm{mg} / \mathrm{kg} \\
0.2 \mathrm{mg} / \mathrm{kg}\end{array}$ & Fix-bed gasifier & $\begin{array}{l}\text { Multiple-crop study to evaluate their potential to } \\
\text { combine biomass production to convert into } \\
\text { bioenergy and active environment improvement. } \\
\text { The experiment results were used to evaluate the } \\
\text { thermodynamic and economic analysis of a } \\
\text { cogeneration system with a gas engine. }\end{array}$ & [94] \\
\hline \multirow{8}{*}{ Avicennia marina } & \multirow{8}{*}{ Acanthacease } & $\mathrm{Cr}$ & $1.20 \mathrm{mg} / \mathrm{kg}$ & \multirow{8}{*}{$\begin{array}{l}\text { Pretreatment of the biomass via } \\
\text { impregnation of ferric salts }\left(\mathrm{FeCl}_{3}\right. \\
\left.\text { and } \mathrm{Fe}\left(\mathrm{NO}_{3}\right)_{3}\right)\end{array}$} & \multirow{8}{*}{$\begin{array}{l}\text { A study that determined the pretreatment effect on } \\
\text { the performance and properties of the pyrolytic } \\
\text { products and heavy metal (HM) behavior. }\end{array}$} & \multirow{8}{*}{ [84] } \\
\hline & & $\mathrm{Mn}$ & $93.99 \mathrm{mg} / \mathrm{kg}$ & & & \\
\hline & & Co & $1.25 \mathrm{mg} / \mathrm{kg}$ & & & \\
\hline & & $\mathrm{Fe}$ & $863.2 \mathrm{mg} / \mathrm{kg}$ & & & \\
\hline & & $\mathrm{Cu}$ & $19.63 \mathrm{mg} / \mathrm{kg}$ & & & \\
\hline & & $\mathrm{Zn}$ & $108.7 \mathrm{mg} / \mathrm{kg}$ & & & \\
\hline & & As & $3.20 \mathrm{mg} / \mathrm{kg}$ & & & \\
\hline & & $\mathrm{Cd}$ & $0.457 \mathrm{mg} / \mathrm{kg}$ & & & \\
\hline \multirow{2}{*}{ Willow (Salix spp.) } & \multirow{2}{*}{ Salicaceae } & $\mathrm{Cu}$ & $0.29 \mathrm{~mol} / \mathrm{kg}$ & \multirow[t]{2}{*}{ Pyrolysis in a solar reactor } & \multirow{2}{*}{$\begin{array}{l}\text { Investigation to elucidate the combined effect of } \\
\text { toxic metals and heating parameters (temperature } \\
\text { and heating rates) on solar pyrolysis products. }\end{array}$} & \multirow[t]{2}{*}{ [85] } \\
\hline & & $\mathrm{Ni}$ & $0.06 \mathrm{~mol} / \mathrm{kg}$ & & & \\
\hline \multirow{2}{*}{ Broussonetia papyfera } & \multirow{2}{*}{ Moraceae } & $\mathrm{Cd}$ & $1.6 \mathrm{mg} / \mathrm{kg}$ & \multirow{2}{*}{ Adsorption-pyrolysis technology } & \multirow{2}{*}{$\begin{array}{l}\text { A technical proposal intended to increase the } \\
\text { recovery of precious metals from the solid phase } \\
\text { after pyrolysis. }\end{array}$} & \multirow{2}{*}{ [95] } \\
\hline & & $\mathrm{Cu}$ & $6.0 \mathrm{mg} / \mathrm{kg}$ & & & \\
\hline
\end{tabular}


Table 3. Cont

\begin{tabular}{|c|c|c|c|c|c|c|}
\hline Plant Species & Family & Metal(s) & Concentration of Metal * & Process & Aim of the Study & Reference \\
\hline \multirow{11}{*}{ Poplar (Populus spp.) } & \multirow{11}{*}{ Salicaceae } & $\mathrm{Be}$ & $0.01 \mathrm{mg} / \mathrm{kg}$ & \multirow{11}{*}{$\begin{array}{l}\text { Fluidized-bed } \\
\text { gasification technology }\end{array}$} & \multirow{11}{*}{$\begin{array}{l}\text { Identification of a specific treatment and } \\
\text { conventional tar reforming to trap residues of toxic } \\
\text { metals in ashes during the gasification process. }\end{array}$} & \multirow{11}{*}{ [90] } \\
\hline & & $\mathrm{V}$ & $0.05 \mathrm{mg} / \mathrm{kg}$ & & & \\
\hline & & $\mathrm{Cr}$ & $0.67 \mathrm{mg} / \mathrm{kg}$ & & & \\
\hline & & Co & $0.02 \mathrm{mg} / \mathrm{kg}$ & & & \\
\hline & & $\mathrm{Ni}$ & $0.70 \mathrm{mg} / \mathrm{kg}$ & & & \\
\hline & & $\mathrm{Cu}$ & $22.89 \mathrm{mg} / \mathrm{kg}$ & & & \\
\hline & & $\mathrm{Zn}$ & $19.68 \mathrm{mg} / \mathrm{kg}$ & & & \\
\hline & & Se & $0.05 \mathrm{mg} / \mathrm{kg}$ & & & \\
\hline & & $\mathrm{Cd}$ & $0.02 \mathrm{mg} / \mathrm{kg}$ & & & \\
\hline & & Sn & $0.02 \mathrm{mg} / \mathrm{kg}$ & & & \\
\hline & & $\mathrm{Pb}$ & $0.16 \mathrm{mg} / \mathrm{kg}$ & & & \\
\hline Zea mays & Poaceae & $\mathrm{Pb}$ & $\begin{array}{l}\text { In roots: } 306.7 \mathrm{mg} / \mathrm{kg} \\
\text { In steams: } 83.4 \mathrm{mg} / \mathrm{kg} \\
\text { In leaves: } 182.1 \mathrm{mg} / \mathrm{kg}\end{array}$ & $\begin{array}{l}\text { Calorimetry to evaluate properties } \\
\text { of biomass }\end{array}$ & $\begin{array}{l}\text { The study was focused on the estimation of the } \\
\text { combustion heat energy of maize grown in } \\
\text { Pb-polluted soil. }\end{array}$ & [96] \\
\hline $\begin{array}{l}\text { Miscanthusxgiganteus } \\
\text { Sida hermaphrodita }\end{array}$ & $\begin{array}{l}\text { Poaceae } \\
\text { Malvaceae }\end{array}$ & $\begin{array}{l}\mathrm{Pb} \\
\mathrm{Zn} \\
\mathrm{Cd}\end{array}$ & $\begin{array}{c}\mathrm{BDL}^{* *} \\
3.45-112.47 \mathrm{mg} / \mathrm{kg} \\
0.220-1.928 \mathrm{mg} / \mathrm{kg}\end{array}$ & $\begin{array}{l}\text { Thermogravimetric study and } \\
\text { kinetic analysis of pyrolysis of } \\
\text { toxic-metal-polluted biomass }\end{array}$ & $\begin{array}{l}\text { The first study on pyrolysis kinetics of biomass } \\
\text { from phytoremediation. }\end{array}$ & [97] \\
\hline Cenchrus purpureus & Poaceae & $\mathrm{Cd}$ & $50.35 \mathrm{mg} / \mathrm{kg}$ & Pyrolysis & $\begin{array}{l}\text { Coupled phytoremediation and bacterial inoculation } \\
\text { to increase the removal of } C d \text { and evaluation of its } \\
\text { use as feedstock in fuel production. }\end{array}$ & [98] \\
\hline \multirow{2}{*}{ Broussonetia papyrifera } & \multirow{2}{*}{ Moraceae } & $\mathrm{Cd}$ & $1.6 \mathrm{mg} / \mathrm{kg}$ & \multirow{2}{*}{ Pyrolysis } & \multirow{2}{*}{$\begin{array}{l}\text { To elucidate the influence and fate of HMs and the } \\
\text { potential for recovering bioenergy. }\end{array}$} & \multirow{2}{*}{ [32] } \\
\hline & & $\mathrm{Cu}$ & $6 \mathrm{mg} / \mathrm{kg}$ & & & \\
\hline
\end{tabular}

${ }^{*}$ Based on dry matter of biomass. ${ }^{* *}$ Below the detectable level. 


\subsection{Biochemical Conversion of Metals-Polluted Biomass}

\subsubsection{Liquid Biofuels}

Besides solids and gases, liquid biofuels can be produced via thermal and biochemical conversion. These fuels have been extensively researched mainly to replace conventional liquid fuels (diesel and petrol) [99], representing a carbon-neutral resource contributing to the mitigation of greenhouse gas (GHG) emissions [100].

For instance, bioethanol has gained interest in several countries around the world [101,102]. This biofuel has a high octane level; thus, the mix with gasoline is affordable, reducing the emission of pollutants and improving the performance of engines, and it is also produced by fermentation of edible or non-edible biomass [103]. Similarly, biodiesel can be obtained from feedstock oil such as non-edible oil or edible oil [104].

Biofuels can be classified based on the feedstock used for their production, i.e., first, second, and third generations of non-edible lignocellulosic biomass, into non-edible plants, microorganisms, and wastes, respectively [103]. However, to increase the added value of these fuels, the incorporation of biomass from phytoremediation has gained interest, and some studies have been done; for example, the versatile plant hemp (Cannabis sativa L.) has been reported as a multi-use crop to phytoremediate soils polluted with toxic metals, radionuclides, and organic compounds and also as potential feedstock for bioenergy production [105].

In this sense, there are reports mentioning that the oil content in hemp seeds is between 25 and 35\% w/w [106], making them promissory feedstock for biodiesel production processes [107]. Biodiesel produced from hemp seed oil presents physicochemical properties comparable to values reported in the fuel standard specifications for biodiesel fuel blendstock, i.e., ASTM D6751 [108,109].

Phytoremediation hemp coupled to bioenergy processes has been recently investigated to include concept designs considering biodiesel production, bioethanol, biogas and combined heat, and power [105].

Depending on the type of contaminant and fate in the plant, the bioenergy production process should be carefully selected since contaminants could be released into the environment; this aspect represents the first barrier to facilitating incorporation of phytoremediation biomass into bioenergy conversion; some safety and regulatory aspects are still under revision [110].

In an interesting study, Rheay et al. [105] suggested that hemp is a strong candidate for generating profit from phytoremediation operations due to its ability to remove a wide spectrum of contaminants; this plant is feasible to be used as raw material for high-value fuels, such as biodiesel, bioethanol, biogas, and combined heat and power. In a complete manner, this plant represents a versatile feedstock to produce multi-bioenergy resources that deserve to be studied in detail.

A similar case was reported by Jung et al. [111], where the biomass of non-edible cockspur grass (Echinochloa crus-galli) seeds from phytoremediation trials were used to produce biodiesel. The phytoremediation potential of toxic metals was tested while monitoring the growth of the grass and, simultaneously, the direct conversion of cockspur grass seeds into biodiesel. The study reported that the process responsible for the remotion of toxic metals was translocation from water into the plant; several authors have previously reported this process for other species, such as wheat [112], water hyacinth [113], and peony [114]. Jung et al. [111] also observed that during cockspur grass growth in the solution of the metals, the adsorption and translocation of the metals by the grass was initiated only after three weeks of growth; therefore, the control of the maximum amount of toxic metal uptake by each plant should be considered for the continuous growth of cockspur grass and the adsorption of toxic metals.

Another attractive plant object of analysis in the bioenergy and phytoremediation sectors during the past years is Miscanthus, an herbaceous perennial with high yield and environmental adaptability. Wang et al. [115] published a thorough review in which several aspects related to Miscanthus, i.e., biological properties, biofuel production, and 
phytoremediation of polluted soils, were analyzed. For instance, Wu et al. [116] reported important information about the metal tolerance of Miscanthus to single metals or mixtures where roots are the predominant part of toxic metal accumulation, and the capacity of accumulation varies significantly depending on the Miscanthus species.

Ito et al. [117] reported different by-products derived from the fermentation process of Miscanthus phytoremediation biomass, such as hydrogen energy, by electrolyzing the extract of cellulose. Lee et al. [118] estimated the average cellulose content of $M$. floridulus, M. sinensis, M. sacchariflorus, and M. $x$ giganteus per gram of biomass. They calculated the bioethanol production in the range of $0.211-0.233 \mathrm{~g}$ of bioethanol per gram of raw biomass.

Liu et al. [119] evaluated a panel of 166 sorghum accessions grown in Cd-contaminated fields in two consecutive years to analyze the effect of different accessions and organs on phytoremediation by determining the accumulation of $\mathrm{Cd}$ in steams, leaves, and grains. After this first stage, three accessions of sorghum were identified as a potential resource to couple with bioethanol production, safe grains, and forage. The parameter identified to select the above-mentioned types of sorghum was the positive association of $\mathrm{Cd}$ accumulation with bioenergy traits, such as biomass, stem brix, internode numbers, and plant height. This study proposed a farming system that could reduce $\mathrm{Cd}$ in soil and obtain an economic return by producing bioethanol, safe grains, and forage.

In this same sense, a holistic study was carried out by Tian et al. [120] that evaluated the morphological responses, biomass yield, and bioenergy potential during the entire growth period (167 days) of sweet sorghum with different concentration of $\mathrm{Cd}$ (1-100 mg/kg soil). The experiment was carried out under laboratory conditions, and authors found that morphological characteristics are not significantly different at a $\mathrm{Cd}$ concentration of $\leq 5 \mathrm{mg} / \mathrm{kg}$ soil. The root was the organ of Cd accumulation; thus, the reutilization of the aerial biomass would not be influenced. According to theoretical estimations, the predicted ethanol yield was 3.65, 3.05, 3.14, 2.69, 1.15, and $0.41 \mathrm{t} / \mathrm{y} / \mathrm{hm}^{2}$ for 1, 5, 10, 30, 50 , and $100 \mathrm{mg} / \mathrm{kg}$ soil Cd concentrations, respectively. The calculations were done as first reported by Zhang et al. [121]. The authors concluded that the high biomass production and $\mathrm{Cd}$ accumulation capacity of sweet sorghum is a good combination, making it a viable candidate for bioenergy production in Cd-contaminated soils.

It has been demonstrated that in superior plants, different phytoremediation routes are presented, although the time used to phytoremediate polluted soils normally becomes longer due to the slow growth of most of the species [122]; these aspects need to be dealt with to convert this environmental biotechnology into a more attractive and affordable option. Studies are being implemented to turn this drawback into opportunities; for example, Pilipović et al. [123] reported long-term poplar phytoremediation in which biomass productivity and carbon storage during a rotation of Populus deltoides Bartr. Ex Marsch $\times$ P. nigra L. DN34 and P. nigra $\times$ P. maximowiczii A. Henry NM6 grown for landfill phytoremediation were tested. The researchers evaluated specific gravity and fiber composition and determined the biomass recalcitrance of trees grown in landfills versus those grown for biomass production on an agricultural site. Regarding phytoaccumulation and phytoextraction, specificity was observed associated with cloning and tissue types. DN34 had a higher pollutant concentration, while NM6 showed superiority in terms of the mean annual uptake of HMs, i.e., $28 \%$ to $657 \%$ greater than the other. Trees grown in landfill soil exhibited 15\% greater lignin content than those grown in agricultural soil, contributing to $46 \%$ lower glucose yield. Increased lignification has been associated with abiotic stresses, i.e., drought-stress resistance [124]. This study also corroborated the general trend of NM6 to have greater productivity and carbon storage potential than DN34 in the phytoremediation system [125]. It was also found that the mannan, xylan, and glucan content was $37 \%, 21 \%$, and $26 \%$ greater, respectively, for trees growing in non-polluted soils than trees growing in polluted soils. For this study, the results showed that the use of phytoremediation biomass is not a viable alternative to produce biofuels, since the above-mentioned carbohydrate content is significantly lower in trees grown in polluted soils. 
One of the advantages of phytotechnologies is the use of native metal accumulator species that guarantee the success of the implementation. For instance, Tiwari et al. [126] reported the current phytoremediation situation in India, where the availability of different phytoremediator trees is abundant, for example, Azadirachta indica, Acacia nilotica, Prosopis juliflora, Terminalia arjuna, Pongamia pinnata, and Eucalyptus tereticornis. Special interest is the use of Azaridachta indica and Acacia nilotica not only for their use in traditional medicine, personal care, and the presence of biologically active compounds [127] but also because of restoration of eroded soils and the phytoremediation potential, removing organic compounds [128,129], radionuclides [130], and toxic metals [122,131,132]. The studies report using seeds of $A$. indica from phytoremediation to produce ethanol from biomass fermentation and biodiesel via base-catalyzed transesterification. For the cases of ethanol production, the yield was $1-3 \% w / w$; regarding the composition of primary fatty acids in neem oil, authors found oleic acid, linoleic acid, stearic acid, and palmitic acid ( $42 \%, 19 \%, 18 \%$, and $15 \% w / w$, respectively). Azadirachta biodiesel was mixed with diesel, and the engine performance was measured as specific fuel consumption (SFC) and brake thermal efficiency (BTE), defined as the ratio of brake power output to power input. The study demonstrated lower SFC utilization when the diesel blend was used; this is because of a higher oxygen content and cetane number compared to diesel alone. Regarding the BTE, it was observed that in all the mixtures tested (10-50\%), the thermal brake efficiency was enhanced when the load increased, attributed to an increase in power output with an increase in load. Finally, the study concluded that these species might be used as phytoremediator species to clean up soils polluted with either organic or inorganic pollutants and then the biomass produced might be used as feedstock to produce biofuels that comply with required standards to be blended with commercial fuels.

In the above-reviewed studies, it has been shown that the presence of toxic metals in plants can be controlled to minimize negative effects on bioethanol production in laboratory-scale trials. Different species have been analyzed to determine specific characteristics and process conditions related to this technological platform, such as metal concentration in soils and biomass, distribution of HMs in biomass, saccharification conditions, fermentation, and biofuel yield. The results of the above-mentioned experiments have validated the viability of biochemical conversion processes for fermentation of sugars and transesterification for fatty oils to produce bioethanol and biodiesel from biomass harvested after phytoremediation.

In Table 4 are listed some studies where phytoremediation biomass was used to produce bioethanol, either on a theoretical or on a practical basis. 
Table 4. Use of phytoremediation biomass to produce liquid biofuels.

\begin{tabular}{|c|c|c|c|c|c|c|}
\hline Plant Species & Family & Metals & Concentration of Metal * & Process & Aim of the Study & Reference \\
\hline Eichornia crassipes & Pontederiaceae & $\mathrm{Cr}$ & Data not reported & Fermentation in bioreactor & $\begin{array}{c}\text { Design and implementation of a process to produce } \\
\text { bioethanol by using biomass from the } \\
\text { phytoremediation process }\end{array}$ & [133] \\
\hline Brassica napus L. & Brassicaceae & $\mathrm{Cd}$ & $43.7-72.48 \mathrm{ug} / \mathrm{g}$ & Fermentation in bioreactor & $\begin{array}{c}\text { To evaluate three pretreatments to } B \text {. napus to } \\
\text { enhance biomass enzymatic saccharification and } \\
\text { bioethanol production and to propose a } \\
\text { cost-effective combined technology to process } \\
\text { polluted biomass }\end{array}$ & [134] \\
\hline \multirow{2}{*}{ Cenchrus purpureum } & \multirow{2}{*}{ Poaceae } & $\mathrm{Zn}$ & $2701.97 \mathrm{mg} / \mathrm{kg}$ & \multirow{2}{*}{ Fermentation in bioreactor } & \multirow{2}{*}{$\begin{array}{l}\text { Use of Napier grass to remediate soil polluted with } \\
\text { metals and evaluate the production of bioethanol } \\
\text { with the biomass from phytoremediation }\end{array}$} & \multirow{2}{*}{ [135] } \\
\hline & & $\mathrm{Cr}$ & $74.24 \mathrm{mg} / \mathrm{kg}$ & & & \\
\hline Pogonatherum crinitum & Poaceae & Dye textile effluents & Data not reported & Fermentation in bioreactor & $\begin{array}{l}\text { Define the processing conditions for the production } \\
\text { of bioethanol incorporating biomass through } \\
\text { fermentation in a phytoreactor }\end{array}$ & [136] \\
\hline \multirow{4}{*}{ Nicptiana tabacum L. } & \multirow{4}{*}{ Solanaceae } & Tobacco shoots & & \multirow{11}{*}{ Fermentation in bioreactor } & \multirow{11}{*}{$\begin{array}{l}\text { The pretreatment of biomass (acid, alkaline, } \\
\text { organosolv) to select the best option } \\
\text { to produce bioethanol }\end{array}$} & \multirow{11}{*}{ [137] } \\
\hline & & $\mathrm{Zn}$ & $440 \mathrm{mg} / \mathrm{kg}$ & & & \\
\hline & & $\mathrm{Mn}$ & $195 \mathrm{mg} / \mathrm{kg}$ & & & \\
\hline & & $\mathrm{Fe}$ & $165 \mathrm{mg} / \mathrm{kg}$ & & & \\
\hline \multirow{3}{*}{ Salix viminalis } & \multirow{3}{*}{ Salicaceae } & Willow wood & & & & \\
\hline & & $\mathrm{Mn}$ & $263 \mathrm{mg} / \mathrm{kg}$ & & & \\
\hline & & $\mathrm{Fe}$ & $155 \mathrm{mg} / \mathrm{kg}$ & & & \\
\hline \multirow{4}{*}{ Betula pendula } & \multirow{4}{*}{ Betulaceae } & Birch wood & & & & \\
\hline & & $\mathrm{Zn}$ & $139 \mathrm{mg} / \mathrm{kg}$ & & & \\
\hline & & $\mathrm{Mn}$ & $69 \mathrm{mg} / \mathrm{kg}$ & & & \\
\hline & & $\mathrm{Fe}$ & $40 \mathrm{mg} / \mathrm{kg}$ & & & \\
\hline Sorghum spp. & Poaceae & $\mathrm{Cd}$ & $\begin{array}{l}\text { In steams: } 0.5-16.54 \mathrm{mg} / \mathrm{kg} \\
\text { In leaves: } 0.03-6.42 \mathrm{mg} / \mathrm{kg} \\
\text { In grains: } 0.03-6.42 \mathrm{mg} / \mathrm{kg}\end{array}$ & $\begin{array}{l}\text { Theoretical study to determine } \\
\text { technical feasibility }\end{array}$ & $\begin{array}{l}\text { Prospective study to evaluate the feasibility of } \\
\text { coupling phytoremediation and } \\
\text { bioethanol production }\end{array}$ & [119] \\
\hline \multirow{6}{*}{ Helianthus annuus L. } & \multirow{6}{*}{ Asteraceae } & As & $10.2-43.9 \mathrm{mg} / \mathrm{kg}$ & \multirow{6}{*}{ Fermentation in bioreactor } & \multirow{6}{*}{$\begin{array}{l}\text { To determine the technical feasibility of the } \\
\text { incorporation of } H \text {. annuus L to produce bioethanol } \\
\text { under a platform of biorefinery }\end{array}$} & \multirow{6}{*}{ [63] } \\
\hline & & $\mathrm{Cd}$ & $40.3-161 \mathrm{mg} / \mathrm{kg}$ & & & \\
\hline & & $\mathrm{Cu}$ & $14.2-75.3 \mathrm{mg} / \mathrm{kg}$ & & & \\
\hline & & $\mathrm{Ni}$ & $0.5-99.1 \mathrm{mg} / \mathrm{kg}$ & & & \\
\hline & & $\mathrm{Pb}$ & $29.1-149 \mathrm{mg} / \mathrm{kg}$ & & & \\
\hline & & $\mathrm{Zn}$ & $128-808 \mathrm{mg} / \mathrm{kg}$ & & & \\
\hline
\end{tabular}


Table 4. Cont.

\begin{tabular}{|c|c|c|c|c|c|c|}
\hline Plant Species & Family & Metals & Concentration of Metal * & Process & Aim of the Study & Reference \\
\hline \multirow{16}{*}{ Miscathus $x$ giganteus } & \multirow{16}{*}{ Poaceae } & \multirow{3}{*}{$\mathrm{Fe}$} & In roots: $20,238-27,162 \mathrm{mg} / \mathrm{kg}$ & \multirow{16}{*}{$\begin{array}{l}\text { Theoretical estimation of } \\
\text { bioethanol yield from biomass }\end{array}$} & \multirow{16}{*}{$\begin{array}{l}\text { Study to evaluate the effect of toxic metals on } \\
\text { growth of Miscanthus } x \text { giganteus, a species widely } \\
\text { used as feedstock in biofuel production }\end{array}$} & \multirow{16}{*}{ [138] } \\
\hline & & & In stems: $130-316 \mathrm{mg} / \mathrm{kg}$ & & & \\
\hline & & & In leaves: $1107-5227 \mathrm{mg} / \mathrm{kg}$ & & & \\
\hline & & \multirow[t]{2}{*}{$\mathrm{Mn}$} & In stems: $46-128 \mathrm{mg} / \mathrm{kg}$ & & & \\
\hline & & & In leaves: $176-445 \mathrm{mg} / \mathrm{kg}$ & & & \\
\hline & & \multirow{3}{*}{$\mathrm{Ti}$} & In roots: $20,238-27,162 \mathrm{mg} / \mathrm{kg}$ & & & \\
\hline & & & In stems: $130-316 \mathrm{mg} / \mathrm{kg}$ & & & \\
\hline & & & In leaves: $1107-5227 \mathrm{mg} / \mathrm{kg}$ & & & \\
\hline & & \multirow{3}{*}{$\mathrm{Zr}$} & In roots: $112-269 \mathrm{mg} / \mathrm{kg}$ & & & \\
\hline & & & In stems: $1 \mathrm{mg} / \mathrm{kg}$ & & & \\
\hline & & & In leaves: $2-19 \mathrm{mg} / \mathrm{kg}$ & & & \\
\hline & & \multirow{3}{*}{$\mathrm{Cu}$} & In roots: $21-60 \mathrm{mg} / \mathrm{kg}$ & & & \\
\hline & & & In stems: $1 \mathrm{mg} / \mathrm{kg}$ & & & \\
\hline & & & In leaves: $1 \mathrm{mg} / \mathrm{kg}$ & & & \\
\hline & & \multirow{2}{*}{ As } & In roots: $7-8 \mathrm{mg} / \mathrm{kg}$ & & & \\
\hline & & & In leaves: BDL ** & & & \\
\hline \multirow{6}{*}{ Ricinus communis $\mathrm{L}$. } & \multirow{6}{*}{ Euphorbiaceae } & In beans & & \multirow{6}{*}{ Oil fatty acid analysis } & \multirow{6}{*}{$\begin{array}{l}\text { To determine the tolerance and the physiological } \\
\text { and biochemical response of the plant to metals } \\
\text { To characterize the chemical composition of the oil } \\
\text { from seeds in order to determine the viability to be } \\
\text { transesterified to produce biodiesel }\end{array}$} & \multirow{6}{*}{ [139] } \\
\hline & & $\mathrm{Cd}$ & $2.6-9.5 \mathrm{mg} / \mathrm{kg}$ & & & \\
\hline & & $\mathrm{Pb}$ & $2.2-197.4 \mathrm{mg} / \mathrm{kg}$ & & & \\
\hline & & $\mathrm{Fe}$ & $187.5-673.1 \mathrm{mg} / \mathrm{kg}$ & & & \\
\hline & & $\mathrm{Mn}$ & $0.5-58.4 \mathrm{mg} / \mathrm{kg}$ & & & \\
\hline & & $\mathrm{Zn}$ & $39.1-224.3 \mathrm{mg} / \mathrm{kg}$ & & & \\
\hline
\end{tabular}

* Based on dry matter of biomass. ${ }^{* *}$ Below the detectable level. 


\subsubsection{Gaseous Bioenergy}

As previously explained, biomass can be converted to liquid and solid biofuels via thermal and biochemical processes; this biomass can also be transformed into gaseous fuels, i.e., biomethane, biohydrogen, biopropane, and biobutane, via gasification, thermochemical processes, or anaerobic digestion, also known as anaerobic fermentation of biomass [140]. This energy form also includes biogas, which contains primarily methane, butane, and propane [141].

There are reports of interest that exemplify the incorporation of biomass from phytoremediation into gaseous bioenergy generation processes. Helianthus annuus and Silybum marianum were used to phytoremediate soils polluted with $\mathrm{As}, \mathrm{Cd}, \mathrm{Cu}, \mathrm{Pb}$, and $\mathrm{Zn}$ [142] collected from a mining site. These reports consisted of using harvested biomass produced in polluted and non-polluted soils to determine the effect of contaminants on morphology and the biogas production potential (BPP) of this biomass. The shoots of S. marianum and the stem and leaves of $H$. annuus were anaerobically digested and showed a BPP of 194-223 $\mathrm{mL} \mathrm{g}^{-1}$ for S. marianum that was higher than that for H. annuus $\left(134-154 \mathrm{~mL} \mathrm{~g}^{-1}\right.$ ). There were no significant differences between polluted and non-polluted soils regarding average methane concentrations of $63.1 \%$ and $65.7 \% \mathrm{v} / \mathrm{v}$ for $S$. marianum and $H$. annuus, respectively. The highest biogas production was found from seeds of $H$. annuus (356-473 $\mathrm{mL} \mathrm{g}^{-1} ; 71 \%$ of $\mathrm{CH}_{4}$ ) after 9 days of anaerobic digestion. The aerial vegetative biomass of $H$. annuus had higher calorific values than that of $S$. marianum (17.1 and $14.3 \mathrm{MJ} \mathrm{kg}^{-1}$, respectively). Finally, the authors did not report any limitation of the potential energy recovery due to trace metals.

In a recent study published by Wang et al. [143], species belonging to different families (Lamiaceae, Asteraceae, Crassulaceae, Solanaceae, Phytolaccaceae, and Pteridaceae) were evaluated as phytoremediators of toxic-metal-polluted soils and the bioenergy generation was measured. The results reported biogas production potentials for E. haichowensis, S. alfredii, S. nigrum, P. americana, and P. vittate as $259.2 \pm 2.9,238.7 \pm 4.2,135.9 \pm 0.9$, $129.5 \pm 2.9$, and $106.8 \pm 2.1 \mathrm{~mL} / \mathrm{g}$, respectively. In addition, specific effects associated with metals and species were observed; for instance, the presence of $\mathrm{Cu}$ at $1000 \mathrm{mg} / \mathrm{kg}$ increased the cumulative biogas production, the daily methane production, and the methane yield of E. haichowensis. For S. alfredii, the presence of $\mathrm{Zn}(\geq 500 \mathrm{mg} / \mathrm{kg})$ showed a negative impact on the methane content in biogas and daily methane production. Regarding the presence of $\mathrm{Mn}(5000-10,000 \mathrm{mg} / \mathrm{kg})$, an increment was observed and then a decrease when the concentration of the element reached $20,000 \mathrm{mg} / \mathrm{kg}$. The cumulative biogas production was not affected at these range concentrations (Cd (1-200 mg/kg), Pb (125-200 mg/kg), and As $(1250-10,000 \mathrm{mg} / \mathrm{kg})$ ) for S. nigrum, S. alfredii, and P. vittata, respectively. The experiment demonstrated that anaerobic digestion has a promissory potential for the disposal of metal-contaminated biomass.

Besides the experiments for removing toxic metals commonly found in soils, there is interest in evaluating the phytoremediation efficiency for mercury present as $\mathrm{Hg}^{0}, \mathrm{Hg}^{2+}$, and $\mathrm{Hg}^{+}$. This element can be found in gaseous form $\left(\mathrm{H}^{0}\right)$ in the atmosphere or metallic $\mathrm{Hg}$ if found in the liquid state [144]. An experiment carried out by Rollinson et al. [145] aimed to determine the treatability of Lepidium sativum L. and Mentha spicata L. biomass grown in compost spiked with mercury after cultivation for 20 and 68 days, respectively, via anaerobic digestion. The biomass was harvested and used as raw material for bench-scale anaerobic digesters operated in continuous-stirred batch mode for 10 days. The inhibition of anaerobic biogas production due to the bacteriostatic effect of $\mathrm{Hg}$ was observed. During the same experiment, canola oil-sulfide polymer derived from biowaste was used as an intermediary treatment to test its capacity for extracting mercury from samples prior to anaerobic digestion and from the post-experimentation reactor digestate. It was found that the polymer removed mercury from the digestate with a $40-50 \%$ efficacy, resulting in a feasible option to remediate sludge and a technical step to be combined with anaerobic digestion of biomass from phytoremediation. 
Among other species, Helianthus annuus has been extensively used to remove metals from soils. For instance, Lee et al. [146] investigated the long-term stability performance of the anaerobic digestion process of a continuous-stirred-tank reactor (CSTR) operated for 1100 days with sunflower harvested in a potential toxic-metal-contaminated site (all parts of the sunflower were used, such as stem, leaf, and flower). It was found that soluble metal concentrations were lower than the reported inhibitory level and the reactor performance remained stable up to an organic loading rate (OLR) of $2.0 \mathrm{~g}$ volatile solids (VS)/L/day at a hydraulic retention time (HRT) of 20 days. Additionally, changes in microbial communities during digestion were evaluated by pyrosequencing, and cellulose degrader populations were found to be established, i.e., Bacteroidetes (29.6-63.6\%), Firmicutes (6.5-18.2\%), Proteobacteria (0.4-15.4\%), Tenericutes $(0.3-32.3 \%)$, Choloflexi (0.3-6.0\%), and Spirochaete (0.25-10.1\%). When considering a different taxonomic level, i.e., class, the composition was mainly Bacteroidia (28.6-63.5\%), Clostridia (6.4-15.3\%), Deltaproteobacteria (0.1-8.9\%), Anaerolineae (0.2-5.5\%), and Betaproteobacteria (0.2-3.8\%). As mentioned earlier, the most abundant phylum was Bacteriodetes, which is frequently found in anaerobic reactors, with an important role as fermenters and acidogens [147]; Firmicutes also steadily increased over time, ranging from $7.1 \%$ to $18.2 \%$. Firmicutes are known to be involved in hydrolyzing polymers such as cellulose and lignin [148].

Two phyla of archaeal communities were detected, i.e., Euryarchaeota (54.2-98.8\%) and Crenarchaeote (1.2-45.8\%). The dominant archaeal sequences were Methanobacteriales (10.2-69.7\%), Methanosarcinales (9.3-17.1\%), and Methanomicrobiales (0.2-1.1\%) at the order level. During anaerobic digestion, only Methanobacteriales increased significantly.

After this exhaustive microbiological analysis, the authors concluded that microbial metabolism was maintained appropriately, and anaerobic digestion is feasible for the disposal of toxic-metal-containing crop residues from phytoremediation sites. The authors mentioned that only $\mathrm{Cu}$ and $\mathrm{Zn}$ were detected in solution, whereas $\mathrm{Cd}, \mathrm{Pb}$, and $\mathrm{Ni}$ were barely observed during the experimental periods. The reason was suggested to be the precipitation of these metals with sulfur and hydroxide [149].

Some other studies have focused on unused polluted soils where plants such as Arundo donax L. grow and can be coupled to bioenergy production. A. donax has shown high potential to be used in phytoremediation processes, and its harvested biomass represents a resource [150]. The authors proposed using the phytoremediation biomass in two different processes, depending on the time of harvesting: anaerobic digestion with fresh biomass before winter and combustion of dry canes in late winter.

The study reported that $A$. donax is able to remove $3.87 \mathrm{~kg} \mathrm{ha}^{-1}$ of $\mathrm{Zn}, 2.09 \mathrm{~kg} \mathrm{ha}^{-1}$ of $\mathrm{Cu}$, and $0.007 \mathrm{~kg} \mathrm{ha}^{-1}$ of $\mathrm{Cd}$ from soil. Regarding biomass production, it was found that plants grown in polluted soils produced less biomass $\left(7.67 \pm 1.66\right.$ tons of dry mass ha $\left.{ }^{-1}\right)$ compared to plants growing in non-polluted soils $\left(13.23 \pm 1.33\right.$ tons of dry mass ha $\left.{ }^{-1}\right)$ in the first year, but no differences were found in the second and third years of cultivation. According to the results, this study concludes that $A$. donax may be an excellent option for phytoextraction and energy production due to the higher yield and HM uptake, so this species has become a viable solution for phytoremediation of soils polluted with HMs while at the same time producing energy.

As for other bioenergy processes, the pretreatment of biomass has been studied to improve biofuel production yield and performance. A study aimed to determine the anaerobic digestion (AD) feasibility for the release of biogas and HMs from contaminated rice straw pretreated with an alkaline solution [151]. The results showed that $\mathrm{NaOH}$ pretreatment boosted the release of biogas and metals from straw via AD. The optimal conditions of the pretreatment, i.e., $\mathrm{NaOH} 6 \%(w / w)$ with a solid-to-solution ratio of 1:20, yielded $446.3 \mathrm{~mL} / \mathrm{g}$ of total biogas and methane and $263.5 \mathrm{~mL}$ of volatile solids were obtained, which were $22.18 \%$ and $41.59 \%$ higher than those of the control without $\mathrm{NaOH}$ pretreatment.

Pretreating rice straw with $\mathrm{NaOH}$ enhances the release of metals from the biomass, i.e., 86.9-97.6\%, degrading the lignin and provoking the release and combining of hemicellulose 
or cellulose through enzymatic action, which leads to enhancing hydrolysis and higher biogas production via anaerobic digestion. In this study, Illumina sequencing identified Bacteroidetes and Firmicutes (proteolytic and hydrogen producers, respectively) as dominant phyla in biogas residues, while the growth of Methanospirillum and Methanosaeta in anaerobically digested effluent was promoted.

Dual studies regarding the removal of toxic compounds from the soil via phytoremediation and incorporating this biomass for biogas productions have increased during the past years and have confirmed that the biomass that grows in polluted soils has a high potential for biogas production. The knowledge about this conversion technology has been enriched in the technical aspects and operational conditions and in the composition and dynamics of microbial communities involved in specific stages of the biological process, providing a better understanding of the whole process and ensuring the success of this technology.

In Table 5 are described several experiments focused on the biochemical conversion of biomass to produce biogas and the theoretical estimation of bioethanol production. 
Table 5. Biochemical conversion of phytoremediation biomass to produce biogas.

\begin{tabular}{|c|c|c|c|c|c|c|}
\hline Plant Species & Family & Metal(s) & $\begin{array}{c}\text { Concentration of Metal } \\
(\mathrm{mg} / \mathrm{kg}) *\end{array}$ & Process & Aim of the Study & Reference \\
\hline \multirow{15}{*}{$\begin{array}{l}\text { Helianthus annuus } \\
\text { Silybum marianum }\end{array}$} & \multirow{15}{*}{ Asteraceae } & H. annuus & & \multirow{15}{*}{ Anaerobic digestion } & \multirow{15}{*}{$\begin{array}{l}\text { To measure the biogas production } \\
\text { potential, aerobic biodegradability, and } \\
\text { calorific values of polluted biomass }\end{array}$} & \multirow{15}{*}{ [142] } \\
\hline & & $\mathrm{Cd}$ & $0.1-0.9$ & & & \\
\hline & & $\mathrm{Cu}$ & $5.5-24.7$ & & & \\
\hline & & $\mathrm{Pb}$ & $0.1-175$ & & & \\
\hline & & $\mathrm{Zn}$ & $77-314$ & & & \\
\hline & & $\mathrm{Mn}$ & $34-212$ & & & \\
\hline & & $\mathrm{Fe}$ & $70-375$ & & & \\
\hline & & As & $0.01-4.9$ & & & \\
\hline & & S. marianum & & & & \\
\hline & & $\mathrm{Cd}$ & $0.01-2.8$ & & & \\
\hline & & $\mathrm{Cu}$ & $6.7-14.1$ & & & \\
\hline & & $\mathrm{Pb}$ & $0.01-117$ & & & \\
\hline & & $\mathrm{Zn}$ & $40-248$ & & & \\
\hline & & $\mathrm{Fe}$ & $33-463$ & & & \\
\hline & & As & $0.01-6.4$ & & & \\
\hline \multirow{11}{*}{$\begin{array}{l}\text { Elshotzia haichowensis } \\
\text { Sedum alfredii } \\
\text { Solanum nigrum } \\
\text { Phytolacca americana } \\
\text { Pteris vittata }\end{array}$} & \multirow{11}{*}{$\begin{array}{c}\text { Lamiaceae } \\
\text { Crassulaceae } \\
\text { Solanaceae } \\
\text { Phytolaccaceae } \\
\text { Pteridaceae }\end{array}$} & & Shoots of E. haichowensis & \multirow{11}{*}{ Anaerobic digestion } & \multirow{11}{*}{$\begin{array}{l}\text { Assessment of the bioenergy generation } \\
\text { capability of trace-metal-polluted plants }\end{array}$} & \multirow{11}{*}{ [143] } \\
\hline & & $\mathrm{Cu}$ & 253 & & & \\
\hline & & & Shoots of S. alfredii & & & \\
\hline & & $\mathrm{Pb}$ & 102.5 & & & \\
\hline & & $\mathrm{Zn}$ & 3216 & & & \\
\hline & & & Shoots of S. nigrum & & & \\
\hline & & $\mathrm{Cd}$ & 55.7 & & & \\
\hline & & & Shoot of $P$. americana & & & \\
\hline & & $\mathrm{Mn}$ & 22,596 & & & \\
\hline & & & Leaves of $P$. vittata & & & \\
\hline & & As & 470.6 & & & \\
\hline
\end{tabular}


Table 5. Cont.

\begin{tabular}{|c|c|c|c|c|c|c|}
\hline Plant Species & Family & Metal(s) & $\begin{array}{c}\text { Concentration of Metal } \\
(\mathrm{mg} / \mathrm{kg}) *\end{array}$ & Process & Aim of the Study & Reference \\
\hline \multirow{5}{*}{ Helianthus annuus } & \multirow{5}{*}{ Asteraceae } & $\mathrm{Cd}$ & 3.21 & \multirow{5}{*}{ Anaerobic digestion } & \multirow{5}{*}{$\begin{array}{l}\text { To investigate the release of potential toxic } \\
\text { metals according to degradation of toxic } \\
\text { metals containing biomass during the } \\
\text { production of biogas }\end{array}$} & \multirow{5}{*}{ [152] } \\
\hline & & $\mathrm{Pb}$ & 13.1 & & & \\
\hline & & $\mathrm{Cu}$ & 26.3 & & & \\
\hline & & $\mathrm{Ni}$ & 1.45 & & & \\
\hline & & $\mathrm{Zn}$ & 56.0 & & & \\
\hline \multirow{4}{*}{ Oryza sativa } & \multirow{4}{*}{ Poaceae } & $\mathrm{Cd}$ & $1.33-2.20$ & \multirow{4}{*}{ Anaerobic digestion } & \multirow{4}{*}{$\begin{array}{l}\text { To study the feasibility of anaerobic } \\
\text { digestion for the release of biogas and } \\
\text { potential toxic metals from contaminated } \\
\text { rice straw pretreated with } \mathrm{NaOH}\end{array}$} & \multirow{4}{*}{ [151] } \\
\hline & & $\mathrm{Cu}$ & $5.25-7.88$ & & & \\
\hline & & $\mathrm{Pb}$ & $1.03-2.90$ & & & \\
\hline & & $\mathrm{Zn}$ & $75.13-77.88$ & & & \\
\hline \multirow{10}{*}{ Arundo donax $\mathrm{L}$. } & \multirow{10}{*}{ Poaceae } & $\mathrm{Cr}$ & $1.48-4.9$ & \multirow{10}{*}{ Anaerobic digestion } & \multirow{10}{*}{$\begin{array}{l}\text { To evaluate the use of } A \text {. donux } \mathrm{L} \text {. as a } \\
\text { phytoextractor and estimate the energy } \\
\text { production via anaerobic digestion of the } \\
\text { polluted biomass }\end{array}$} & \multirow{10}{*}{ [150] } \\
\hline & & $\mathrm{Mn}$ & $20.68-93.91$ & & & \\
\hline & & $\mathrm{Fe}$ & $56.21-90$ & & & \\
\hline & & Co & $0.02-0.16$ & & & \\
\hline & & $\mathrm{Cu}$ & $4.94-8.86$ & & & \\
\hline & & $\mathrm{Zn}$ & $25.65-121$ & & & \\
\hline & & As & $0.05-0.26$ & & & \\
\hline & & Mo & $1.39-2.57$ & & & \\
\hline & & $\mathrm{Cd}$ & $0.02-0.21$ & & & \\
\hline & & $\mathrm{Pb}$ & $0.76-0.12$ & & & \\
\hline Pteris vittata & Pteridaceae & As & 2665 & Anaerobic digestion & $\begin{array}{l}\text { To study the reduction of polluted biomass } \\
\text { of } P \text {. vittate and the removal of As via } \\
\text { anaerobic digestion }\end{array}$ & [153] \\
\hline \multirow{5}{*}{ Helianthus annuus } & \multirow{5}{*}{ Asteraceae } & $\mathrm{Cd}$ & 3.21 & \multirow{5}{*}{ Anaerobic digestion } & \multirow{5}{*}{$\begin{array}{l}\text { To investigate the long-term stability of the } \\
\text { performance of anaerobic digestion for the } \\
\text { treatment of polluted biomass from } \\
\text { phytoremediation processes }\end{array}$} & \multirow{5}{*}{ [146] } \\
\hline & & $\mathrm{Cu}$ & 29.17 & & & \\
\hline & & $\mathrm{Ni}$ & 1.45 & & & \\
\hline & & $\mathrm{Pb}$ & 13.1 & & & \\
\hline & & $\mathrm{Zn}$ & 56.0 & & & \\
\hline
\end{tabular}


Table 5. Cont.

\begin{tabular}{|c|c|c|c|c|c|c|}
\hline Plant Species & Family & Metal(s) & $\begin{array}{c}\text { Concentration of Metal } \\
(\mathrm{mg} / \mathrm{kg}) *\end{array}$ & Process & Aim of the Study & Reference \\
\hline \multirow{4}{*}{$\begin{array}{l}\text { Lepidium sativum } \mathrm{L} \text {. } \\
\text { Mentha spicata } \mathrm{L} \text {. }\end{array}$} & \multirow{4}{*}{$\begin{array}{l}\text { Brassicaceae } \\
\text { Lamiaceae }\end{array}$} & & L. sativum & \multirow{4}{*}{ Anaerobic digestion } & \multirow{4}{*}{$\begin{array}{l}\text { To determine the mercury-induced } \\
\text { bacteriostatic toxicity during the anaerobic } \\
\text { digestion of polluted biomass }\end{array}$} & \multirow{4}{*}{ [145] } \\
\hline & & $\mathrm{Hg}$ & 0.4928 & & & \\
\hline & & & M. spicata & & & \\
\hline & & $\mathrm{Hg}$ & 2.9149 & & & \\
\hline Sorghum bicolor $\mathrm{L}$. & Poaceae & $\mathrm{Cd}$ & $27.3-137.90$ & $\begin{array}{l}\text { Theoretical estimation of } \\
\text { bioethanol production }\end{array}$ & $\begin{array}{l}\text { To assess morphological responses, } \\
\text { biomass yield, and bioenergy potential } \\
\text { during the entire growth of sweet } \\
\text { sorghum with different Cd stress }\end{array}$ & [120] \\
\hline
\end{tabular}




\section{Economic Feasibility and Other Benefits of the Revalorization of the Phytoremediation Biomass}

Jiang et al. [154] recently proposed an integrated approach to enhance phytoremediation's financial viability, produce energy, and recover high-value elements. This model assessed the economic viability of phytoremediation and proposed that high-biomass-yield plant species can significantly achieve a financial return from recovering elements such as $\mathrm{Ni}, \mathrm{Pt}$, and $\mathrm{As}$, if the phytoremediation is well managed. In addition to phytoextraction, the authors also proposed extensive on-field experimentation to achieve commercialization and further valorization of its by-products [155].

According to Jiang et al. [154], threshold values of elemental concentrations in plant biomass (dry weight) for hyperaccumulators are $>10,000 \mu \mathrm{g} / \mathrm{g}$ of $\mathrm{Mn}$ and $\mathrm{Zn},>1000 \mu \mathrm{g} / \mathrm{g}$ of As, Co, Cu, Ni, Se, and Pb, and >100 $\mu \mathrm{g} / \mathrm{g}$ of Cd. Van Der Ent et al. [156] introduced the term agromining to involve technologies growing a metal accumulator plant as a crop and then harvesting the biomass and drying, ashing, and processing it to recover target $\mathrm{HMs}$, such as As, $\mathrm{Se}, \mathrm{Cd}, \mathrm{Cu}, \mathrm{Co}, \mathrm{La}, \mathrm{Mn}, \mathrm{Ni}, \mathrm{Pb}, \mathrm{Tl}$, and $\mathrm{Zn}$. However, Haller and Jonsson [157] stated that phytoremediation is not attractive to farmers, especially for subsistence farming in economically vulnerable regions. Van der Ent et al. [156] stated that a large-scale demonstration of agromining is first needed to work through operational challenges and provide evidence of profitability. For this reason, according to Marques et al. [158], biomass resulting from phytoremediation could be used as a by-product with added value, namely to produce biomass-derived energy, within a circular economy concept and global sustainable development. Therefore, phytoremediation suggests a sustainable approach to the disposal and effective use of HM-containing biowastes [159].

The revalorization of biomass from phytoremediation has brought new possibilities to generate value-added products. Besides, biomass pyrolysis has been recognized as the most promising thermochemical technique for large-scale electricity and heat recovery from HMpolluted biomass and biofuel synthesis. Therefore, phytoremediation reduces pollution and can be coupled to energy, revenues, and even feedstock production, boosting a circular economy, carbon sequestration, and cogeneration of phytoproducts and highly-valued by-products. According to Ghosh and Maiti [160], the economics of these approaches to enhance phytoremediation, production energy, and recovery of high-value elements should be assessed. Simultaneously, scientists should also conduct an environmental cost-benefit analysis based on well-designed, large-scale, and long-term field trials.

However, metal recovery by phytoremediation must not be the ultimate goal of phytotechnologies. According to Yan et al. [161], soil function restoration is an important contribution of phytotechnologies to ecosystems. Plants have the ability to absorb ionic compounds in the soil, even at low concentrations, through their root systems, establishing rhizosphere ecosystems to accumulate toxic metals and modulate their availability, thereby reclaiming the polluted soils, stabilizing soil fertility [162], enhancing the nutrient cycling in soil, controlling erosion, and providing aesthetic value [163].

To date, other technologies have been installed to work along phytoremediation. It has been stated that coupling phytoremediation to biochar, biofuel, or heat production gives far-reaching social and economic benefits [31]. Yang et al. [164] compared three oil crop rotation systems for effective use and remediation of HM-contaminated agricultural soil and soil conservation. Other authors have used nanotechnology to increase pollutants' dissipation during phytoremediation of polluted soils [165], i.e., phytotechnologies have improved the benefits of soil conservation and social and economic benefits. In addition, recent research on phytoremediation has greatly expanded the fundamental knowledge on molecular biology and soil ecology regarding microbial niches. This is because environmental conditions could hamper the establishment of symbiotic interactions and the general recommendations for optimized use of plant-microbe combinations in HM-contaminated soils [166]. Lin et al. [167] stated that rhizosphere properties, enzyme activities, and associated rhizosphere microorganisms modulate phytoremediation in HM-polluted soils. 
According to Dilks et al. [155], biomass pyrolysis valorization from phytoremediation is a complex process. Therefore, the design of integrated phytoextraction and pyrolysis process methods should be carried out according to subsequent advancements to deliver consistent and reliable phytoextractor valorization procedures [155]:

(a) The parameters of the pyrolysis should be determined by the requested final products, the inorganic content, and the method of heating.

(b) The selection of metal accumulator plant species is determined by various conditions that concern either the soil decontamination process or the biomass pyrolysis process.

(c) The extrinsic moisture and mineral content add new requirements related to the period of the harvest of phytoextractors rich in ash.

(d) The concentrations of toxic metals concealed in the char of phytoextractors cultivated with soil decontamination purposes must be well known.

Therefore, the combination of phytoremediation and food production is under development and in the process of technological maturity. However, it can potentially allow safe food production on polluted soil, restringing the pollutants' transfer to the food chain, while the soil pollutant pool is reduced [157].

As explained above, the recovery of elements offers possibilities for treating metalenriched biomass produced using phytoremediation technologies; some of these options are presented in Table 6.

Table 6. Viable and feasible options for the treatment of potential toxic-metal-enriched plants produced by phytoremediation.

\begin{tabular}{|c|c|c|c|c|}
\hline Plant & Elements Recovered & Condition & Additional Benefit & Reference \\
\hline $\begin{array}{l}\text { Thlaspi caerulescens } \\
\text { (Jord) and Salix } \\
\text { viminalis (L.) }\end{array}$ & $\mathrm{Cd}$ and $\mathrm{Zn}$ & $\begin{array}{l}\text { Pyrolysis occurred under } \\
\text { reducing conditions. }\end{array}$ & $\begin{array}{l}\text { Recycling of the bottom } \\
\text { ash as fertilizer and } \\
\text { production of energy } \\
\text { derived from pyrolysis }\end{array}$ & [168] \\
\hline Higher plants & $\begin{array}{c}\text { Aqueous phase with } \mathrm{N}, \\
\mathrm{P} \text {, and } \mathrm{K} \text {, and } \\
\text { solid residue } \\
\text { containing HMs }\end{array}$ & $\begin{array}{c}\text { Pyrolysis or } \\
\text { hydrothermal liquefaction }\end{array}$ & $\begin{array}{l}\text { Generation of bio-crude } \\
\text { for upgrading to } \\
\text { advanced biofuels }\end{array}$ & [33] \\
\hline $\begin{array}{l}\text { Contaminated plants } \\
\text { and energy crops }\end{array}$ & HMs & $\begin{array}{c}\text { Thermochemical processes } \\
\text { (pyrolysis, gasification, } \\
\text { combustion, } \\
\text { and liquefaction) }\end{array}$ & $\begin{array}{l}\text { Electricity and } \\
\text { heat recovery }\end{array}$ & [31] \\
\hline Mixtures of biomass & $\begin{array}{c}\mathrm{C}, \mathrm{H}, \mathrm{O}, \mathrm{N}, \mathrm{P}, \mathrm{Cl}, \mathrm{S} \\
\text { and } \mathrm{HMs}\end{array}$ & Pyrolysis & $\begin{array}{l}\text { Biofuels and } \\
\text { solid biochar }\end{array}$ & [169] \\
\hline $\begin{array}{l}\text { Woody gymnosperm, } \\
\text { angiosperm, and } \\
\text { herbaceous plants }\end{array}$ & $\begin{array}{l}\mathrm{Cd}, \mathrm{Cu}, \mathrm{Pb}, \mathrm{Zn}, \mathrm{Co}, \mathrm{Cr}, \\
\text { and } \mathrm{Ni}\end{array}$ & Pyrolysis & $\begin{array}{l}\text { Heat and gas } \\
\text { by-products }\end{array}$ & [155] \\
\hline
\end{tabular}

\section{Emerging Risks and Gaps}

New technologies could involve human and environmental risks. Therefore, phytotechnologies should be used knowledgeably and stringently screened before environmental release. Phytoremediation is an exciting field of research growing day by day, at the crossroads of agronomy, environmental engineering, ecology, economy, and social sciences; therefore, transdisciplinary work is highly encouraged.

It is crucial to know the destination of pollutants in plants to make decisions about the fate of metals in downstream processing, which would be incorporated into bioenergy production.

In the same way, understanding the pollutants' fate in plants allows us to estimate the possible transfer of metals in some by-products or residues during biofuel production. The use of edible plants during phytoremediation is an additional risk. Therefore, the use of non-edible crops must be encouraged in bioremediation technologies [170]. 
As a global trend, many authors have stated that phytoremediation must focus on the recent advances in food production, dissipation of pollutants, biomass valorization, energy production, ecological balance, and knowledge areas regarding social welfare with potential applications and benefits in the environmental and agri-food industries, i.e., several well-designed, large-scale, and long-term field trials must be carried out. The above implies the use of dozens of uncontrolled variables, and therefore the design and management of phytoremediation systems become complex, highlighting the need for multiple expert collaborative works. Additionally, the effect of working together with cutting-edge technologies such as nanotechnologies along with phytoremediation has been studied to dissipate pollutants from contaminated soils. Still, most of the results are preliminary or were produced during short-term laboratory studies [171].

Food security, water, energy, and pollution remediation are high-priority issues regarding sustainable development, and all of them are inextricably linked [172]. In recent decades, unexpected and common contaminants in soil, water, and air have threatened food security and human and environmental health. New environmentally friendly and cost-effective strategies are in the experimental phase and are scarce or not available for real-life use. An accurate mapping of soil, water, and air pollution is missing to prevent the transfer of ubiquitous pollutants into the food chain. This map is necessary to design and implement suitable remediation strategies that could use bioremediation technologies such as phytoremediation, bioaugmentation, or biostimulation as cost-effective strategies. According to Rai et al. [173], eco-feasible technological innovations such as nanotools and farmers' awareness could boost local economies and livelihoods with certain financial guarantees.

Although during the past years, there has been an important generation of scientific knowledge addressing aspects related to the incorporation of contaminated biomass into bioenergy production processes, there is still a need for more specialized technical information for specific plant species.

Technical conditions for better thermochemical conversion processes must be improved, but also more specialized products should also be obtained as secondary products of phytoremediation's plant biomass processing. Besides, the full concept of biorefineries and all the technologies involved should be studied considering the multi-objective optimization toward economic, social, and environmental viability through sustainable routes. Therefore, biorefineries could reduce agricultural wastes or phytoremediation biomass sustainably in the circular bioeconomy.

A noteworthy point here is that advanced phytoremediation is still struggling to transit from the laboratory to the field [82]. It is expected that information from long-term field studies will demonstrate the in situ economic feasibility. Therefore, selecting suitable plant species and some specific conditions for the phytoremediation of HM-polluted sites is not an easy task but will precede their commercial success.

\section{Conclusions}

Phytoremediation is an attractive technology to alleviate the contamination of toxicmetal-polluted soils.

In most contaminated sites, non-edible metal-tolerant and metal accumulator plant species have been used to remove these toxic compounds. After phytoremediation, many authors have addressed the disposal of this biomass and have demonstrated that there is enormous potential in incorporating it into bioenergy and avoiding $\mathrm{HMs}^{\prime}$ introduction into the food chain.

In this sense, methods have been developed to valorize this biomass and convert it into high-value-added products, such as biofuels. It has been demonstrated that bioenergy production is promising and might contribute to the global renewable energy demand. These biofuels can be used for heating, fuel, electricity, and transportation, among others. This review discusses examples where the incorporation of polluted biomass from phytore- 
mediation into bioenergy production and other by-products was achieved, indicating that integrated phytoremediation and bioenergy generation is a sustainable process.

In the future, it can be expected that a clearer engineering scenario is reached where metal residues are mostly retained in fewer fractions in a more predictable way to avoid their environmental remobilization. These metal-enriched fractions should not be dead ends but rather the source of novel catalysts or reusable materials. Finally, the process engineering that is being developed can greatly benefit from the fundamental research on plant biology where traditional and cutting-edge genomics can help scientists better control the transit of these elemental pollutants through the plant and compartmentalize and concentrate the metal fraction in a more predictable manner that facilitates the design of industrial facilities and biorefineries.

Author Contributions: Conceptualization, V.-N.E.; investigation, V.-N.E., F.-L.F., P.-C.J.M., and V.R.I.; writing-original draft preparation, V.-N.E., F.-L.F., P.-C.J.M., and V.-R.I. All authors have read and agreed to the published version of the manuscript.

Funding: This research was funded by CONACYT-CB (grant number CB-287137).

Institutional Review Board Statement: Not applicable.

Informed Consent Statement: Not applicable.

Data Availability Statement: Data sharing not applicable.

Acknowledgments: V.-N.E. thanks the DIQEB_-Universidad de Guanajuato for all the support and facilities to develop this work. V.-N.E. thanks especially B.V.-F. for her patient technical support during the preparation of this manuscript. P.-C.J.M. thanks CONACYT-CB for financially supporting this research (grant CB-287137).

Conflicts of Interest: The authors declare no conflict of interest.

\section{References}

1. Li, G.; Sun, G.; Ren, Y.; Luo, X.; Zhu, Y. Urban soil and human health: A review. Eur. J. Soil Sci. 2018, 69, 196-215. [CrossRef]

2. Yu, Y.H.; Su, J.F.; Shih, Y.; Wang, J.; Wang, P.Y.; Huang, C.P. Hazardous wastes treatment technologies. Water Environ. Res. 2020, 92, 1833-1860. [CrossRef] [PubMed]

3. Ali, H.; Khan, E.; Ilahi, I. Environmental chemistry and ecotoxicology of hazardous heavy metals: Environmental persistence, toxicity, and bioaccumulation. J. Chem. 2019, 2019, 1-14. [CrossRef]

4. Li, C.; Zhou, K.; Qin, W.; Tian, C.; Qi, M.; Yan, X.; Han, W. A review on heavy metals contamination in soil: Effects, sources, and remediation techniques. Soil Sediment Contam. 2019, 28, 380-394. [CrossRef]

5. Becerra-Castro, C.; Lopes, A.R.; Vaz-Moreira, I.; Silva, E.F.; Manaia, C.M.; Nunes, O.C. Wastewater reuse in irrigation: A microbiological perspective on implications in soil fertility and human and environmental health. Environ. Int. 2015, 75, 117-135. [CrossRef] [PubMed]

6. Biswas, B.; Qi, F.; Biswas, J.K.; Wijayawardena, A.; Khan, M.A.I.; Naidu, R. The fate of chemical pollutants with soil properties and processes in the climate change paradigm-A review. Soil Syst. 2018, 2, 51. [CrossRef]

7. Shukla, K.P.; Singh, N.K.; Sharma, S. Bioremediation: Developments, current practices and perspectives. Genet. Eng. Biotechnol. J. 2010, 3, 1-20.

8. Singh, A.; Ward, O.P. Biotechnology and bioremediation-An overview. Biodegrad. Bioremediat. 2004, 1, 1-17.

9. Vázquez-Núñez, E.; Pena-Castro, J.M.; Fernandez-Luqueño, F.; Cejudo, E.; Maria, G.; Garcia-Castaneda, M.C. A review on genetically modified plants designed to phytoremediate polluted soils: Biochemical responses and international regulation. Pedosphere 2018, 28, 697-712. [CrossRef]

10. Sarwar, N.; Imran, M.; Shaheen, M.R.; Ishaque, W.; Kamran, M.A.; Matloob, A.; Rehim, A.; Hussain, S. Phytoremediation strategies for soils contaminated with heavy metals: Modifications and future perspectives. Chemosphere 2017, 171, 710-721. [CrossRef]

11. Wang, L.; Ji, B.; Hu, Y.; Liu, R.; Sun, W. A review on in situ phytoremediation of mine tailings. Chemosphere 2017, 184, 594-600. [CrossRef]

12. Shackira, A.; Puthur, J.T. Phytostabilization of heavy metals: Understanding of principles and practices. In Plant-Metal Interactions, 1st ed.; Srivastava, S., Srivastava, K.A., Suprasanna, P., Eds.; Springer: Cham, Switzerland, 2019; Volume 1, pp. $263-282$.

13. Suman, J.; Uhlik, O.; Viktorova, J.; Macek, T. Phytoextraction of heavy metals: A promising tool for clean-up of polluted environment? Front. Plant Sci. 2018, 9, 1476. [CrossRef]

14. Awa, S.H.; Hadibarata, T. Removal of heavy metals in contaminated soil by phytoremediation mechanism: A review. Water Air Soil Pollut. 2020, 231, 1-15. [CrossRef] 
15. Singh, J.; Sharma, M.; Basu, S. Heavy metal ions adsorption and photodegradation of remazol black XP by iron oxide/silica monoliths: Kinetic and equilibrium modelling. Adv. Powder Technol. 2018, 29, 2268-2279. [CrossRef]

16. Majeed, A.; Muhammad, Z.; Ahmad, H.; Inayat, N.; Siyar, S. Heavy metal-contaminated soils: Weeds as potential phytoremediation agents-Issues and prospects. In Cellular and Molecular Phytotoxicity of Heavy Metals, 1st ed.; Faisal, M., Saquib, Q., Alatar, A.A., Al-Khedhairy, A.A., Eds.; Springer: Cham, Switzerland, 2020; Volume 1, pp. 179-190.

17. Medina-Pérez, G.; Fernández-Luqueño, F.; Vazquez-Nuñez, E.; López-Valdez, F.; Prieto-Mendez, J.; Madariaga-Navarrete, A.; Miranda-Arámbula, M. Remediating polluted soils using nanotechnologies: Environmental benefits and risks. Pol. J. Environ. Stud. 2019, 28, 1-18. [CrossRef]

18. Sarabia-Castillo, C.R.; Pérez-Moreno, A.; Galindo-Ortiz, A.; Fraga-Pecina, N.; Pérez-Hernández, H.; Medina-Pérez, G.; Fernández-Luqueño, F. Phytonanotechnology and environmental remediation. In Phytonanotechnology, 1st ed.; Thajuddin, N., Mathew, S., Eds.; Elsevier: Amsterdam, The Netherlands, 2020; pp. 159-185.

19. Farraji, H.; Zaman, N.Q.; Tajuddin, R.; Faraji, H. Advantages and disadvantages of phytoremediation: A concise review. Int. J. Environ. Technol. Sci. 2016, 2, 69-75.

20. Tripathi, V.; Edrisi, S.A.; Abhilash, P.C. Towards the coupling of phytoremediation with bioenergy production. Renew. Sustain. Energy Rev. 2016, 57, 1386-1389. [CrossRef]

21. Grzegórska, A.; Rybarczyk, P.; Rogala, A.; Zabrocki, D. Phytoremediation-From environment cleaning to energy generationCurrent status and future perspectives. Energies 2020, 13, 2905. [CrossRef]

22. Salt, D.E.; Blaylock, M.; Kumar, N.P.; Dushenkov, V.; Ensley, B.D.; Chet, I.; Raskin, I. Phytoremediation: A novel strategy for the removal of toxic metals from the environment using plants. Biotechnology 1995, 13, 468-474. [CrossRef] [PubMed]

23. Anderson, C.W.; Brooks, R.R.; Stewart, R.B.; Simcock, R. Harvesting a crop of gold in plants. Nature 1998, 395, 553-554. [CrossRef]

24. Hou, D.; O'Connor, D.; Igalavithana, A.D.; Alessi, D.S.; Luo, J.; Tsang, D.C.; Sparks, D.L.; Yamauchi, Y.; Rinklebe, J.; Ok, Y.S. Metal contamination and bioremediation of agricultural soils for food safety and sustainability. Nat. Rev. Earth Environ. 2020, 1, 366-381. [CrossRef]

25. Wijekoon, P.; Wickramasinghe, C.; Athapattu, B.; Narayana, M.; de Alwis, A.; Vithanage, M. Biomass valorization and phytoremediation as integrated technology for municipal solid waste management for developing economic context. Biomass Convers. Biorefin. 2020, 1, 1-20. [CrossRef]

26. Cui, X.; Zhang, J.; Wang, X.; Pan, M.; Lin, Q.; Khan, K.Y.; Yan, B.; Li, T.; He, Z.; Yang, X. A review on the thermal treatment of heavy metal hyperaccumulator: Fates of heavy metals and generation of products. J. Hazard. Mater. 2020, 1, 123832. [CrossRef] [PubMed]

27. Song, U.; Park, H. Importance of Biomass management acts and policies after phytoremediation. J. Ecol. Environ. 2017, 41, 13. [CrossRef]

28. Alzate, C.A.C.; Toro, J.C.S.; Peña, Á.G. Fermentation, thermochemical and catalytic processes in the transformation of biomass through efficient biorefineries. Catal. Today 2018, 302, 61-72. [CrossRef]

29. Choudhary, P.; Assemany, P.P.; Naaz, F.; Bhattacharya, A.; de Siqueira Castro, J.; do Couto Couto E de, A.; Calijuri, M.L.; Pant, K.K.; Malik, A. A review of biochemical and thermochemical energy conversion routes of wastewater grown algal biomass. Sci. Total Environ. 2020, 726, 137961. [CrossRef] [PubMed]

30. Jain, P.; Jain, A.; Singhai, R.; Jain, S. Effect of bio-degradation and non degradable substances in environment. Int. J. Life Sci. 2017, $1,58-64$.

31. Dastyar, W.; Raheem, A.; He, J.; Zhao, M. Biofuel production using thermochemical conversion of heavy metal-contaminated biomass (HMCB) harvested from phytoextraction process. Chem. Eng. J. 2019, 358, 759-785. [CrossRef]

32. Han, Z.; Guo, Z.; Zhang, Y.; Xiao, X.; Peng, C. Potential of pyrolysis for the recovery of heavy metals and bioenergy from contaminated broussonetia papyrifera biomass. Bioresources 2018, 13, 2932-2944. [CrossRef]

33. Raikova, S.; Piccini, M.; Surman, M.K.; Allen, M.J.; Chuck, C.J. Making light work of heavy metal contamination: The potential for coupling bioremediation with bioenergy production. J. Chem. Technol. Biotechnol. 2019, 94, 3064-3072. [CrossRef]

34. Wang, L.; Hou, D.; Shen, Z.; Zhu, J.; Jia, X.; Ok, Y.S.; Tack, F.M.; Rinklebe, J. Field trials of phytomining and phytoremediation: A critical review of influencing factors and effects of additives. Crit. Rev. Environ. Sci. Technol. 2020, 50, 2724-2774. [CrossRef]

35. Liu, Q.; Chmely, S.C.; Abdoulmoumine, N. Biomass treatment strategies for thermochemical conversion. Energy Fuels 2017, 31, 3525-3536. [CrossRef]

36. Thao, N.T.N.L.; Chiang, K.-Y. The migration, transformation and control of trace metals during the gasification of rice straw. Chemosphere 2020, 260, 127540. [CrossRef]

37. Naaz, F.; Bhattacharya, A.; Pant, K.K.; Malik, A. Impact of heavy metal laden algal biomass on hydrothermal liquefaction and biorefinery approach. Process Saf. Environ. Prot. 2021, 145, 141-149. [CrossRef]

38. Ronda, A.; Gómez-Barea, A.; Haro, P.; de Almeida, V.; Salinero, J. Elements partitioning during thermal conversion of sewage sludge. Fuel Process. Technol. 2019, 186, 156-166. [CrossRef]

39. Cui, X.; Shen, Y.; Yang, Q.; Kawi, S.; He, Z.; Yang, X.; Wang, C.-H. Simultaneous syngas and biochar production during heavy metal separation from $\mathrm{Cd} / \mathrm{Zn}$ hyperaccumulator (Sedum alfredii) by gasification. Chem. Eng. J. 2018, 347, 543-551. [CrossRef]

40. Qian, F.; Zhu, X.; Liu, Y.; Shi, Q.; Wu, L.; Zhang, S.; Chen, J.; Ren, Z.J. Influences of temperature and metal on subcritical hydrothermal liquefaction of hyperaccumulator: Implications for the recycling of hazardous hyperaccumulators. Environ. Sci. Technol. 2018, 52, 2225-2234. [CrossRef] 
41. Lei, M.; Dong, Z.; Jiang, Y.; Longhurst, P.; Wan, X.; Zhou, G. Reaction mechanism of arsenic capture by a calcium-based sorbent during the combustion of arsenic-contaminated biomass: A pilot-scale experience. Front. Environ. Sci. Eng. 2019, 13, 24. [CrossRef]

42. Chen, Z.; Xing, R.; Tang, J.; Chen, Z.; Zhang, Z.; Liao, H.; Huang, R.; Wei, D.; Zhou, S. Upcycling of Cd hyperaccumulator biomass into a CdS@C nanocomposite with high photocatalytic performance. ACS Sustain. Chem. Eng. 2019, 8, 1388-1395. [CrossRef]

43. Xing, R.-Z.; Li, J.-X.; Yang, X.-G.; Chen, Z.-W.; Huang, R.; Chen, Z.-X.; Zhou, S.-G.; Chen, Z. Preparation of high-performance CdS@C catalyst using Cd-enriched biochar recycled from plating wastewater. Front. Chem. 2020, 8, 140. [CrossRef]

44. Balakrishnan, M.; Sacia, E.R.; Sreekumar, S.; Gunbas, G.; Gokhale, A.A.; Scown, C.D.; Toste, F.D.; Bell, A.T. Novel pathways for fuels and lubricants from biomass optimized using life-cycle greenhouse gas assessment. Proc. Natl. Acad. Sci. USA 2015, 112, 7645-7649. [CrossRef]

45. Teixeira, T.R.; Ribeiro, C.A.A.S.; dos Santos, A.R.; Marcatti, G.E.; Lorenzon, A.S.; de Castro, N.L.M.; Domingues, G.F.; Leite, H.G.; Mota, P.H.S.; de Almeida Telles, L.A. Forest biomass power plant installation scenarios. Biomass Bioenergy 2018, 108, 35-47. [CrossRef]

46. Peña-Castro, J.M.; Del Moral, S.; Núñez-López, L.; Barrera-Figueroa, B.E.; Amaya-Delgado, L. Biotechnological strategies to improve plant biomass quality for bioethanol production. Biomed. Res. Int. 2017, 2017, 1-10. [CrossRef]

47. Xiu, S.; Shahbazi, A. Bio-Oil production and upgrading research: A review. Renew. Sustain. Energy Rev. 2012, 16, 4406-4414. [CrossRef]

48. Singh, J.; Kalamdhad, A.S. Reduction of heavy metals during composting. Int. J. Environ. Prot. 2012, 2, $36-43$.

49. Yang, K.; Zhu, L.; Zhao, Y.; Wei, Z.; Chen, X.; Yao, C.; Meng, Q.; Zhao, R. A Novel method for removing heavy metals from composting system: The combination of functional bacteria and adsorbent materials. Bioresour. Technol. 2019, $293,122095$. [CrossRef] [PubMed]

50. Viaene, J.; Van Lancker, J.; Vandecasteele, B.; Willekens, K.; Bijttebier, J.; Ruysschaert, G.; De Neve, S.; Reubens, B. Opportunities and barriers to on-farm composting and compost application: A case study from Northwestern Europe. Waste Manag. 2016, 48, 181-192. [CrossRef] [PubMed]

51. Beckers, F.; Awad, Y.M.; Beiyuan, J.; Abrigata, J.; Mothes, S.; Tsang, D.C.; Ok, Y.S.; Rinklebe, J. Impact of biochar on mobilization, methylation, and ethylation of mercury under dynamic redox conditions in a contaminated floodplain soil. Environ. Int. 2019, 127, 276-290. [CrossRef]

52. Bernal Calderón, M.P.; Gómez, X.; Chang, R.; Arco-Lázaro, E.; Clemente Carrillo, R. Strategies for the use of plant biomass obtained in the phytostabilisation of trace-element-contaminated soils. Biomass Bioenergy 2019, 126, 220-230. [CrossRef]

53. Smolinska, B. Green waste compost as an amendment during induced phytoextraction of mercury-contaminated soil. Environ. Sci. Pollut. Res. 2015, 22, 3528-3537. [CrossRef]

54. Yang, Y.; Ge, Y.; Zeng, H.; Zhou, X.; Peng, L.; Zeng, Q. Phytoextraction of cadmium-contaminated soil and potential of regenerated tobacco biomass for recovery of cadmium. Sci. Rep. 2017, 7, 1-10. [CrossRef] [PubMed]

55. Kidd, P.; Mench, M.; Álvarez-López, V.; Bert, V.; Dimitriou, I.; Friesl-Hanl, W.; Herzig, R.; Olga Janssen, J.; Kolbas, A.; Müller, I. Agronomic practices for improving gentle remediation of trace element-contaminated soils. Int. J. Phytoremediat. 2015, 17, 1005-1037. [CrossRef]

56. Novo, L.A.; Castro, P.M.; Alvarenga, P.; da Silva, E.F. Phytomining of rare and valuable metals. Phytoremediation 2017, 469-486. [CrossRef]

57. Wang, Y.; Lü, J.; Feng, D.; Guo, S.; Li, J. A biosorption-pyrolysis process for removal of Pb from aqueous solution and subsequent immobilization of $\mathrm{Pb}$ in the char. Water 2020, 12, 2381. [CrossRef]

58. Harumain, Z.A.; Parker, H.L.; Muñoz García, A.; Austin, M.J.; McElroy, C.R.; Hunt, A.J.; Clark, J.H.; Meech, J.A.; Anderson, C.W.; Ciacci, L. Toward financially viable phytoextraction and production of plant-based palladium catalysts. Environ. Sci. Technol. 2017, 51, 2992-3000. [CrossRef]

59. Li, Y.-M.; Chaney, R.; Brewer, E.; Roseberg, R.; Angle, J.S.; Baker, A.; Reeves, R.; Nelkin, J. Development of a technology for commercial phytoextraction of nickel: Economic and technical considerations. Plant Soil 2003, 249, 107-115. [CrossRef]

60. Rosenkranz, T.; Hipfinger, C.; Ridard, C.; Puschenreiter, M. A nickel phytomining field trial using Odontarrhena chalcidica and Noccaea goesingensis on an Austrian serpentine soil. J. Environ. Manag. 2019, 242, 522-528. [CrossRef] [PubMed]

61. do Nascimento, C.W.A.; Hesterberg, D.; Tappero, R.; Nicholas, S.; da Silva, F.B.V. Citric acid-assisted accumulation of Ni and other metals by Odontarrhena muralis: Implications for phytoextraction and metal foliar distribution assessed by $\mu$-SXRF. Environ. Pollut. 2020, 260, 114025. [CrossRef] [PubMed]

62. Kolbas, A.; Mench, M.; Herzig, R.; Nehnevajova, E.; Bes, C.M. Copper Phytoextraction in tandem with oilseed production using commercial cultivars and mutant lines of sunflower. Int. J. Phytoremediat. 2011, 13, 55-76. [CrossRef]

63. Dhiman, S.S.; Zhao, X.; Li, J.; Kim, D.; Kalia, V.C.; Kim, I.-W.; Kim, J.Y.; Lee, J.-K. Metal accumulation by sunflower (Helianthus annuus L.) and the efficacy of its biomass in enzymatic saccharification. PLoS ONE 2017, 12, e0175845. [CrossRef] [PubMed]

64. Doroshenko, A.; Budarin, V.; McElroy, R.; Hunt, A.J.; Rylott, E.; Anderson, C.; Waterland, M.; Clark, J. Using: In vivo nickel to direct the pyrolysis of hyperaccumulator plant biomass. Green Chem. 2019, 21, 1236-1240. [CrossRef]

65. Fagnano, M.; Visconti, D.; Fiorentino, N. Agronomic approaches for characterization, remediation, and monitoring of contaminated sites. Agronomy 2020, 10, 1335. [CrossRef] 
66. Basharat, Z.; Novo, L.A.B.; Yasmin, A. Genome editing weds CRISPR: What is in it for phytoremediation? Plants 2018, 7, 51. [CrossRef]

67. Seregin, I.V.; Kozhevnikova, A.D. Low-Molecular-Weight ligands in plants: Role in metal homeostasis and hyperaccumulation. Photosynth. Res. 2020,1,1-46. [CrossRef]

68. Ali, S.; Abbas, Z.; Rizwan, M.; Zaheer, I.E.; Yavas, I.; Ünay, A.; Abdel-Daim, M.M.; Bin-Jumah, M.; Hasanuzzaman, M.; Kalderis, D. Application of floating aquatic plants in phytoremediation of heavy metals polluted water: A review. Sustainability 2020, 12, 1927. [CrossRef]

69. Kumar Yadav, K.; Gupta, N.; Kumar, A.; Reece, L.M.; Singh, N.; Rezania, S.; Ahmad Khan, S. Mechanistic understanding and holistic approach of phytoremediation: A review on application and future prospects. Ecol. Eng. 2018, 120, 274-298. [CrossRef]

70. Guo, M.; Song, W.; Buhain, J. Bioenergy and biofuels: History, status, and perspective. Renew. Sust. Energy Rev. 2015, 42, 712-725. [CrossRef]

71. Tursi, A. A review on biomass: Importance, chemistry, classification, and conversion. Biofuel Res. J. 2019, 6, 962-979. [CrossRef]

72. Okolie, J.A.; Nanda, S.; Dalai, A.K.; Kozinski, J.A. Chemistry and specialty industrial applications of lignocellulosic biomass. Waste Biomass Valoris. 2020, 1, 1-25. [CrossRef]

73. Popp, J.; Kovács, S.; Oláh, J.; Divéki, Z.; Balázs, E. Bioeconomy: Biomass and biomass-based energy supply and demand. New Biotechnol. 2020, 1, 76-84. [CrossRef]

74. Chen, W.-H.; Lin, B.-J.; Lin, Y.-Y.; Chu, Y.-S.; Ubando, A.T.; Show, P.L.; Ong, H.C.; Chang, J.-S.; Ho, S.-H.; Culaba, A.B. Progress in biomass torrefaction: Principles, applications and challenges. Prog. Energy Combust. 2021, 82, 100887. [CrossRef]

75. Chiodini, A.; Bua, L.; Carnelli, L.; Zwart, R.; Vreugdenhil, B.; Vocciante, M. Enhancements in biomass-to-liquid processes: Gasification aiming at high hydrogen/carbon monoxide ratios for direct Fischer-Tropsch synthesis applications. Biomass Bioenergy 2017, 106, 104-114. [CrossRef]

76. Solarte-Toro, J.C.; González-Aguirre, J.A.; Giraldo, J.A.P.; Alzate, C.A.C. Thermochemical processing of woody biomass: A review focused on energy-driven applications and catalytic upgrading. Renew. Sustain. Energy Rev. 2021, 136, 110376. [CrossRef]

77. Gomes, H.I. Phytoremediation for Bioenergy: Challenges and opportunities. Environ. Technol. Rev. 2012, 1, 59-66. [CrossRef]

78. Yang, X.; Igalavithana, A.D.; Oh, S.-E.; Nam, H.; Zhang, M.; Wang, C.-H.; Kwon, E.E.; Tsang, D.C.; Ok, Y.S. Characterization of bioenergy biochar and its utilization for metal/metalloid immobilization in contaminated soil. Sci. Total Environ. 2018, 640, 704-713. [CrossRef]

79. Edao, H.G. Heavy metals pollution of soil; Toxicity and phytoremediation techniques. Indian J. Adv. Eng. Res. 2017, 1, $2456-9992$.

80. Aghaalikhani, A.; Savuto, E.; Di Carlo, A.; Borello, D. Poplar from Phytoremediation as a renewable energy source: Gasification properties and pollution analysis. Energy Procedia 2017, 142, 924-931. [CrossRef]

81. Mlonka-Mędrala, A.; Magdziarz, A.; Dziok, T.; Sieradzka, M.; Nowak, W. Laboratory studies on the influence of biomass particle size on pyrolysis and combustion using TG GC/MS. Fuel 2019, 252, 635-645. [CrossRef]

82. Saxena, G.; Purchase, D.; Mulla, S.I.; Saratale, G.D.; Bharagava, R.N. Phytoremediation of heavy metal-contaminated sites: Eco-Environmental concerns, field studies, sustainability issues, and future prospects. In Reviews of Environmental Contamination and Toxicology; Springer: New York, NY, USA, 2019; Volume 249, pp. 71-131.

83. He, J.; Strezov, V.; Kan, T.; Weldekidan, H.; Asumadu-Sarkodie, S.; Kumar, R. Effect of temperature on heavy metal (loid) deportment during pyrolysis of Avicennia marina biomass obtained from phytoremediation. Bioresour. Technol. 2019, 278, 214-222. [CrossRef]

84. He, J.; Strezov, V.; Zhou, X.; Kumar, R.; Kan, T. Pyrolysis of heavy metal contaminated biomass pre-treated with ferric salts: Product characterisation and heavy metal deportment. Bioresour. Technol. 2020, 313, 123641. [CrossRef] [PubMed]

85. Zeng, K.; Li, R.; Minh, D.P.; Weiss-Hortala, E.; Nzihou, A.; He, X.; Flamant, G. Solar pyrolysis of heavy metal contaminated biomass for gas fuel production. Energy 2019, 187, 116016. [CrossRef]

86. Kovacs, H.; Szemmelveisz, K. Disposal options for polluted plants grown on heavy metal contaminated brownfield lands-A review. Chemosphere 2017, 166, 8-20. [CrossRef] [PubMed]

87. Cruz, N.C.; Silva, F.C.; Tarelho, L.A.; Rodrigues, S.M. Critical review of key variables affecting potential recycling applications of ash produced at large-scale biomass combustion plants. Resour. Conserv. Recycl. 2019, 150, 104427. [CrossRef]

88. Yang, J.; Guo, Y.; Yan, Y.; Yang, J.; Wan, X.; Guo, J.; Guo, J.; Chen, T.; Lei, M. Phytoaccumulation of as by Pteris vittata supplied with phosphorus fertilizers under different soil moisture regimes-A field case. Ecol. Eng. 2019, 138, 274-280. [CrossRef]

89. Pogrzeba, M.; Krzyżak, J.; Rusinowski, S.; Werle, S.; Hebner, A.; Milandru, A. Case study on phytoremediation driven energy crop production using Sida hermaphrodita. Int. J. Phytoremediat. 2018, 20, 1194-1204. [CrossRef]

90. Ancona, V.; Caracciolo, A.B.; Campanale, C.; De Caprariis, B.; Grenni, P.; Uricchio, V.F.; Borello, D. Gasification treatment of poplar biomass produced in a contaminated area restored using plant assisted bioremediation. J. Environ. Manag. 2019, 239, 137-141. [CrossRef] [PubMed]

91. Bartoňová, L.; Raclavska, H.; Čech, B.; Kucbel, M. Behavior of Pb during coal combustion: An overview. Sustainability 2019, 11, 6061. [CrossRef]

92. Xiong, X.; Liu, X.; Iris, K.; Wang, L.; Zhou, J.; Sun, X.; Rinklebe, J.; Shaheen, S.M.; Ok, Y.S.; Lin, Z. Potentially toxic elements in solid waste streams: Fate and management approaches. Environ. Pollut. 2019, 253, 680-707. [CrossRef] 
93. He, J.; Strezov, V.; Kumar, R.; Weldekidan, H.; Jahan, S.; Dastjerdi, B.H.; Zhou, X.; Kan, T. Pyrolysis of heavy metal contaminated Avicennia marina biomass from phytoremediation: Characterisation of biomass and pyrolysis products. J. Clean. Prod. 2019, 234, 1235-1245. [CrossRef]

94. Uchman, W.; Skorek-Osikowska, A.; Werle, S. Evaluation of the potential of the production of electricity and heat using energy crops with phytoremediation features. Appl. Therm. Eng. 2017, 126, 194-203. [CrossRef]

95. Han, Z.; Guo, Z.; Zhang, Y.; Xiao, X.; Xu, Z.; Sun, Y. Adsorption-Pyrolysis technology for recovering heavy metals in solution using contaminated biomass phytoremediation. Resour. Conserv. Recycl. 2018, 129, 20-26. [CrossRef]

96. Cheng, S.-F.; Huang, C.-Y.; Lin, Y.-C.; Lin, S.-C.; Chen, K.-L. Phytoremediation of lead using corn in contaminated agricultural land-An in situ study and benefit assessment. Ecotoxicol. Environ. Saf. 2015, 111, 72-77. [CrossRef] [PubMed]

97. Tran, K.-Q.; Werle, S.; Trinh, T.T.; Magdziarz, A.; Sobek, S.; Pogrzeba, M. Fuel characterization and thermal degradation kinetics of biomass from phytoremediation plants. Biomass Bioenergy 2020, 134, 105469. [CrossRef]

98. Wiangkham, N.; Prapagdee, B. Potential of napier grass with cadmium-resistant bacterial inoculation on cadmium phytoremediation and its possibility to use as biomass fuel. Chemosphere 2018, 201, 511-518. [CrossRef] [PubMed]

99. Tsita, K.G.; Kiartzis, S.J.; Ntavos, N.K.; Pilavachi, P.A. Next generation biofuels derived from thermal and chemical conversion of the Greek transport sector. Therm. Sci. Eng. Prog. 2020, 17, 100387. [CrossRef]

100. Ramos, J.; Valdivia, M.; García-Lorente, F.; Segura, A. Benefits and perspectives on the use of biofuels. Microb. Biotechnol. 2016, 9 , 436-440. [CrossRef]

101. Demirbas, A. Tomorrow's biofuels: Goals and hopes. Energy Sources Part A 2017, 39, 673-679. [CrossRef]

102. Sandesh, K.; Ujwal, P. Trends and perspectives of liquid biofuel—Process and industrial viability. Energy Convers. Manag. 2021, 1, 100075.

103. Rodionova, M.V.; Poudyal, R.S.; Tiwari, I.; Voloshin, R.A.; Zharmukhamedov, S.K.; Nam, H.G.; Zayadan, B.K.; Bruce, B.D.; Hou, H.; Allakhverdiev, S.I. Biofuel production: Challenges and opportunities. Int. J. Hydrogen Energy 2017, 42, 8450-8461. [CrossRef]

104. Yadav, C.; Saini, A.; Bera, M.; Maji, P.K. Thermo-Analytical characterizations of biodiesel produced from edible and non-edible oils. Fuel Process. Technol. 2017, 167, 395-403. [CrossRef]

105. Rheay, H.T.; Omondi, E.C.; Brewer, C.E. Potential of hemp (Cannabis sativa L.) for paired phytoremediation and bioenergy production. Glob. Chang. Biol. Bioenergy 2020, 1, 1-12.

106. Liang, J.; Appukuttan Aachary, A.; Thiyam-Holländer, U. Hemp seed oil: Minor components and oil quality. Lipid Technol. 2015, 27, 231-233. [CrossRef]

107. Li, S.-Y.; Stuart, J.D.; Li, Y.; Parnas, R.S. The feasibility of converting Cannabis sativa L. oil into biodiesel. Bioresour. Technol. 2010, 101, 8457-8460. [CrossRef] [PubMed]

108. Mohammed, M.; Atabani, A.; Uguz, G.; Lay, C.-H.; Kumar, G.; Al-Samaraae, R. Characterization of hemp (Cannabis sativa L.) biodiesel blends with euro diesel, butanol and diethyl ether using FT-IR, UV-Vis, TGA and DSC techniques. Waste Biomass Valoris. 2020, 11, 1097-1113. [CrossRef]

109. Rashid, U.; Bhatti, S.; Ansari, T.; Yunus, R.; Ibrahim, M. Biodiesel production from Cannabis sativa oil from Pakistan. Energy Sources Part A 2016, 38, 865-875. [CrossRef]

110. Shrinkhal, R. Coupling phytoremediation appositeness with bioenergy plants: A sociolegal perspective. In Phytoremediation Potential of Bioenergy Plants; Springer: Singapore, 2017; pp. 457-472.

111. Jung, S.; Kim, M.; Moon, H.; Park, Y.-K.; Rinklebe, J.; Park, C.-J.; Kwon, E.E. Valorization of Phytoremediation byproduct via synthesis of biodiesel from cockspur grass (Echinochloa crus-Galli) seed. ACS Sustain. Chem. Eng. 2020, 8, 11588-11595. [CrossRef]

112. Skiba, E.; Kobyłecka, J.; Wolf, W.M. Influence of 2, 4-D and MCPA Herbicides on uptake and translocation of heavy metals in wheat (Triticum aestivum L.). Environ. Pollut. 2017, 220, 882-890. [CrossRef]

113. Eid, E.M.; Shaltout, K.H.; Moghanm, F.S.; Youssef, M.S.; El-Mohsnawy, E.; Haroun, S.A. Bioaccumulation and Translocation of nine heavy metals by Eichhornia crassipes in Nile delta, Egypt: Perspectives for phytoremediation. Int. J. Phytoremediat. 2019, 21, 821-830. [CrossRef] [PubMed]

114. Shen, Z.J.; Chen, Y.S.; Zhang, Z. Heavy metals translocation and accumulation from the rhizosphere soils to the edible parts of the medicinal plant fengdan (Paeonia ostii) grown on a metal mining area, China. Ecotoxicol. Environ. Saf. 2017, 143, 19-27. [CrossRef]

115. Wang, C.; Kong, Y.; Hu, R.; Zhou, G. Miscanthus: A fast-growing crop for environmental remediation and biofuel production. Glob. Chang. Biol. Bioenergy 2021, 13, 58-69. [CrossRef]

116. Wu, D.M.; Chen, X.Y.; Zeng, S.C. Heavy metal tolerance of miscanthus plants and their phytoremediation potential in abandoned mine land. J. Appl. Ecol. 2017, 28, 1397-1406.

117. Ito, M.; Hori, T.; Teranishi, S.; Nagao, M.; Hibino, T. Intermediate-Temperature electrolysis of energy grass miscanthus sinensis for sustainable hydrogen production. Sci. Rep. 2018, 8, 1-9. [CrossRef]

118. Lee, W.; Kuan, W. Miscanthus as cellulosic biomass for bioethanol production. Biotechnol. J. 2015, 10, 840-854. [CrossRef]

119. Liu, Z.-Q.; Li, H.-L.; Zeng, X.-J.; Lu, C.; Fu, J.-Y.; Guo, L.-J.; Kimani, W.M.; Yan, H.-L.; He, Z.-Y.; Hao, H.-Q. Coupling phytoremediation of cadmium-contaminated soil with safe crop production based on a sorghum farming system. J. Clean. Prod. 2020, 275, 123002. [CrossRef]

120. Tian, Y.; Zhang, H.; Guo, W.; Wei, X. Morphological Responses, biomass yield, and bioenergy potential of sweet sorghum cultivated in cadmium-contaminated soil for biofuel. Int. J. Green Energy 2015, 12, 577-584. [CrossRef] 
121. Zhang, C.; Xie, G.; Li, S.; Ge, L.; He, T. The productive potentials of sweet sorghum ethanol in China. Appl. Energy 2010, 87, 2360-2368. [CrossRef]

122. Hasan, M.; Uddin, M.; Ara-Sharmeen, I.F.; Alharby, H.; Alzahrani, Y.; Hakeem, K.R.; Zhang, L. Assisting phytoremediation of heavy metals using chemical amendments. Plants 2019, 8, 295. [CrossRef] [PubMed]

123. Pilipović, A.; Zalesny, R.S., Jr.; Orlović, S.; Drekić, M.; Pekeč, S.; Katanić, M.; Poljaković-Pajnik, L. Growth and physiological responses of three poplar clones grown on soils artificially contaminated with heavy metals, diesel fuel, and herbicides. Int. J. Phytoremediat. 2020, 22, 436-450. [CrossRef]

124. Coskun, D.; Britto, D.T.; Huynh, W.Q.; Kronzucker, H.J. The role of silicon in higher plants under salinity and drought stress. Front. Plant Sci. 2016, 7, 1072. [CrossRef]

125. Zhu, J.; Headlee, W.L.; Gleisner, R.; Pilipović, A.; Acker, J.V.; Bauer, E.O.; Birr, B.A.; Wiese, A.H. Ecosystem services, physiology, and biofuels recalcitrance of poplars grown for landfill phytoremediation. Plants 2020, 9, 1357.

126. Tiwari, J.; Kumar, A.; Kumar, N. Phytoremediation potential of industrially important and biofuel plants: Azadirachta indica and Acacia nilotica. In Phytoremediation Potential of Bioenergy Plants; Springer: Singapore, 2017; pp. 211-254.

127. Islas, J.F.; Acosta, E.; Zuca, G.; Delgado-Gallegos, J.L.; Moreno-Treviño, M.G.; Escalante, B.; Moreno-Cuevas, J.E. An overview of neem (Azadirachta indica) and its potential impact on health. J. Funct. Foods 2020, 74, 104171. [CrossRef]

128. Gupta, T.B.; Lataye, D.H. Adsorption of indigo carmine dye onto Acacia nilotica (Babool) sawdust activated carbon. J. Hazard. Toxic Radioact. Waste 2017, 21, 04017013. [CrossRef]

129. Odoemelam, S.A.; Emeh, U.N.; Eddy, N.O. Experimental and computational chemistry studies on the removal of methylene blue and malachite green dyes from aqueous solution by neem (Azadirachta indica) leaves. J. Taibah Univ. Sci. 2018, 12, 255-265. [CrossRef]

130. Naskar, N.; Banerjee, K. Development of sustainable extraction method for long-lived radioisotopes, 133 Ba and 134 Cs using a potential bio-sorbent. J. Radioanal. Nucl. Chem. 2020, 325, 587-593. [CrossRef]

131. Abdelsalam, I.M.; Elshobary, M.; Eladawy, M.M.; Nagah, M. Utilization of multi-tasking non-edible plants for phytoremediation and bioenergy source-A review. Phyton 2019, 88, 69-90. [CrossRef]

132. Saini, S.; Gill, J.K.; Kaur, J.; Saikia, H.R.; Singh, N.; Kaur, I.; Katnoria, J.K. Biosorption as environmentally friendly technique for heavy metal removal from wastewater. In Fresh Water Pollution Dynamics and Remediation; Springer: Singapore, $2020 ;$ pp. 167-181.

133. Sayago, U.F.C. Design of a sustainable development process between phytoremediation and production of bioethanol with eichhornia crassipes. Environ. Monit. Assess. 2019, 191, 1-8. [CrossRef]

134. Wu, Y.; Wang, M.; Yu, L.; Tang, S.; Xia, T.; Kang, H.; Xu, C.; Gao, H.; Madadi, M.; Alam, A. A mechanism for efficient cadmium phytoremediation and high bioethanol production by combined mild chemical pretreatments with desirable rapeseed stalks. Sci. Total Environ. 2020, 708, 135096. [CrossRef] [PubMed]

135. Ko, C.-H.; Yu, F.-C.; Chang, F.-C.; Yang, B.-Y.; Chen, W.-H.; Hwang, W.-S.; Tu, T.-C. Bioethanol production from recovered napier grass with heavy metals. J. Environ. Manag. 2017, 203, 1005-1010. [CrossRef]

136. Waghmare, P.R.; Watharkar, A.D.; Jeon, B.-H.; Govindwar, S.P. Bio-Ethanol production from waste biomass of Pogonatherum crinitum phytoremediator: An eco-friendly strategy for renewable energy. 3 Biotech 2018, 8, 1-10. [CrossRef] [PubMed]

137. Asad, M.; Menana, Z.; Ziegler-Devin, I.; Bert, V.; Chalot, M.; Herzig, R.; Mench, M.; Brosse, N. Pretreatment of trace elementenriched biomasses grown on phytomanaged soils for bioethanol production. Ind. Crop. Prod. 2017, 107, 63-72. [CrossRef]

138. Pidlisnyuk, V.; Trögl, J.; Stefanovska, T.; Shapoval, P.; Erickson, L. Preliminary results on growing second generation biofuel crop miscanthus $x$ giganteus at the polluted military site in Ukraine. Nova Biotechnol. Chim. 2016, 15, 77-84. [CrossRef]

139. Boda, R.K.; Majeti, N.V.P.; Suthari, S. Ricinus communis L. (Castor Bean) as a potential candidate for revegetating industrial waste contaminated sites in peri-urban greater hyderabad: Remarks on seed oil. Environ. Sci. Pollut. Res. 2017, 24, 19955-19964. [CrossRef]

140. Lee, K.T.; Ofori-Boateng, C. Biofuels: Production technologies, global profile, and market potentials. In Sustainability of Biofuel Production from Oil Palm Biomass; Springer: Singapore, 2013; pp. 31-74.

141. Padilla-Rivera, A.; Paredes, M.G.; Güereca, L.P. A systematic review of the sustainability assessment of bioenergy: The case of gaseous biofuels. Biomass Bioenergy 2019, 125, 79-94. [CrossRef]

142. Hunce, S.Y.; Clemente, R.; Bernal, M.P. Energy production potential of phytoremediation plant biomass: Helianthus annuus and Silybum marianum. Ind. Crop. Prod. 2019, 135, 206-216. [CrossRef]

143. Wang, S.; Wang, J.; Li, J.; Hou, Y.; Shi, L.; Lian, C.; Shen, Z.; Chen, Y. Evaluation of biogas production potential of trace element-contaminated plants via anaerobic digestion. Ecotoxicol. Environ. Saf. 2021, 208, 111598. [CrossRef]

144. Campos, J.; Esbrí, J.; Madrid, M.; Naharro, R.; Peco, J.; García-Noguero, E.; Amorós, J.; Moreno, M.; Higueras, P. Does mercury presence in soils promote their microbial activity? The Almadenejos case (Almadén mercury mining district, Spain). Chemosphere 2018, 201, 799-806. [CrossRef] [PubMed]

145. Rollinson, A.N.; Bhuptani, J.; Beyer, J.; Ismawati, Y.; Radu, T. Anaerobic digestion of mercury phytoextraction crops with intermediary stage bio-waste polymer treatment. Int. J. Phytoremediat. 2020, 22, 1431-1439. [CrossRef]

146. Lee, J.; Kim, J.R.; Jeong, S.; Cho, J.; Kim, J.Y. Long-Term performance of anaerobic digestion for crop residues containing heavy metals and response of microbial communities. Waste Manag. 2017, 59, 498-507. [CrossRef] [PubMed]

147. Jang, H.M.; Kim, J.H.; Ha, J.H.; Park, J.M. Bacterial and methanogenic archaeal communities during the single-stage anaerobic digestion of high-strength food wastewater. Bioresour. Technol. 2014, 165, 174-182. [CrossRef] 
148. Bolzonella, D.; Battista, F.; Mattioli, A.; Nicolato, C.; Frison, N.; Lampis, S. Biological thermophilic post hydrolysis of digestate enhances the biogas production in the anaerobic digestion of agro-waste. Renew. Sustain. Energy Rev. 2020, 134, 110174. [CrossRef]

149. Chen, Y.; Cheng, J.J.; Creamer, K.S. Inhibition of anaerobic digestion process: A review. Bioresour. Technol. 2008, 99, 4044-4064. [CrossRef]

150. Danelli, T.; Sepulcri, A.; Masetti, G.; Colombo, F.; Sangiorgio, S.; Cassani, E.; Anelli, S.; Adani, F.; Pilu, R. Arundo Donax L. Biomass production in a polluted area: Effects of two harvest timings on heavy metals uptake. Appl. Sci. 2021, 11, 1147. [CrossRef]

151. Xin, L.; Guo, Z.; Xiao, X.; Peng, C.; Zeng, P.; Feng, W.; Xu, W. Feasibility of anaerobic digestion on the release of biogas and heavy metals from rice straw pretreated with sodium hydroxide. Environ. Sci. Pollut. Res. 2019, 26, 19434-19444. [CrossRef] [PubMed]

152. Lee, J.; Park, K.Y.; Cho, J.; Kim, J.Y. Releasing characteristics and fate of heavy metals from phytoremediation crop residues during anaerobic digestion. Chemosphere 2018, 191, 520-526. [CrossRef]

153. da Silva, E.B.; Mussoline, W.A.; Wilkie, A.C.; Ma, L.Q. Anaerobic digestion to reduce biomass and remove arsenic from as-hyperaccumulator Pteris vittata. Environ. Pollut. 2019, 250, 23-28. [CrossRef]

154. Jiang, Y.; Lei, M.; Duan, L.; Longhurst, P. Integrating phytoremediation with biomass valorisation and critical element recovery: A UK contaminated land perspective. Biomass Bioenergy 2015, 83, 328-339. [CrossRef]

155. Dilks, R.; Monette, F.; Glaus, M. The major parameters on biomass pyrolysis for hyperaccumulative plants-A review. Chemosphere 2016, 146, 385-395. [CrossRef]

156. Van Der Ent, A.; Baker, A.J.M.; Reeves, R.D.; Chaney, R.L.; Anderson, C.W.N.; Meech, J.A.; Erskine, P.D.; Simonnot, M.O.; Vaughan, J.; Morel, J.L.; et al. Agromining: Farming for metals in the future? Environ. Sci. Technol. 2015, 1, 4773-4780. [CrossRef] [PubMed]

157. Haller, H.; Jonsson, A. Growing food in polluted soils: A review of risks and opportunities associated with combined phytoremediation and food production (CPFP). Chemosphere 2020, 254, 126826. [CrossRef]

158. Marques, A.P.G.C.; Caetano, N.S.C.; Castro, P.M.L. Chapter 12. Strategies for enhancing soil phytoremediation and biomass valorization. In The Handbook of Environmental Remediation; Royal Society of Chemistry: Cambridge, UK, 2020.

159. Lee, J.; Park, K.Y. Conversion of heavy metal-containing biowaste from phytoremediation site to value-added solid fuel through hydrothermal carbonization. Environ. Pollut. 2020, 269, 116127. [CrossRef]

160. Ghosh, D.; Maiti, S.K. Biochar assisted phytoremediation and biomass disposal in heavy metal contaminated mine soils: A review. Int. J. Phytoremediat. 2020, 1-18. [CrossRef] [PubMed]

161. Yan, A.; Wang, Y.; Tan, S.N.; Yusof, M.L.M.; Ghosh, S.; Chen, Z. Phytoremediation: A promising approach for revegetation of heavy metal-polluted land. Front. Plant Sci. 2020, 11, 359. [CrossRef] [PubMed]

162. DalCorso, G.; Fasani, E.; Manara, A.; Visioli, G.; Furini, A. Heavy metal pollutions: State of the art and innovation in phytoremediation. Int. J. Mol. Sci. 2019, 20, 3412. [CrossRef] [PubMed]

163. Burges, A.; Alkorta, I.; Epelde, L.; Garbisu, C. From Phytoremediation of soil contaminants to phytomanagement of ecosystem services in metal contaminated sites. Int. J. Phytoremediat. 2018, 20, 384-397. [CrossRef]

164. Yang, Y.; Zhou, X.; Tie, B.; Peng, L.; Li, H.; Wang, K.; Zeng, Q. Comparison of three types of oil crop rotation systems for effective use and remediation of heavy metal contaminated agricultural soil. Chemosphere 2017, 188, 148-156. [CrossRef] [PubMed]

165. Pérez-Moreno, A.; Sarabia-Castillo, C.R.; Medina-Pérez, G.; Pérez-Hernández, H.; de la Puente, J.R.; González-Pozos, S.; Corlay-Chee, L.; Chamizo-Checa, A.; Campos-Montiel, R.G.; Fernández-Luqueño, F. Nanomaterials modify the growth of crops and some characteristics of organisms from agricultural or forest soils: An experimental study at laboratory, greenhouse and land level. Mex. J. Biotechnol. 2019, 4, 29-49. [CrossRef]

166. Hrynkiewicz, K.; Zloch, M.; Kowalkowski, T.; Baum, C.; Buszewski, B. Efficiency of microbially assisted phytoremediation of heavy-metal contaminated soils. Environ. Rev. 2018, 26, 316-332. [CrossRef]

167. Lin, H.; Liu, C.; Li, B.; Dong, Y. Trifolium repens L. regulated phytoremediation of heavy metal contaminated soil by promoting soil enzyme activities and beneficial rhizosphere associated microorganisms. J. Hazard. Mater. 2020, 402, 123829. [CrossRef]

168. Keller, C.; Ludwig, C.; Davoli, F.; Wochele, J. Thermal treatment of metal-enriched biomass produced from heavy metal phytoextraction. Environ. Sci. Technol. 2005, 39, 3359-3367. [CrossRef]

169. Liu, W.-J.; Li, W.-W.; Jiang, H.; Yu, H.-Q. Fates of chemical elements in biomass during its pyrolysis. Chem. Rev. 2017, 117, 6367-6398. [CrossRef]

170. Prasad, M.N.V. Phytoremediation crops and biofuels. In Sustainable Agriculture Reviews; Springer: Cham, Switzerland, 2015.

171. Amrane, A.; Mohan, D.; Nguyen, T.A.; Assadi, A.A.; Yasin, G. Nanomaterials for Soil Remediation, 1st ed.; Elsevier: Amsterdam, The Netherlands, 2020.

172. Bouyé, M.; Harmeling, S.; Schulz, N.-S. Connecting the Dots: Elements for a Joined-up Implementation of the 2030 Agenda and Paris Agreement; World Resources Institute: Washington, DC, USA; GIZ: Bonn, Germany, 2018. Available online: https://files.wri.org/ s3fs-public/connecting-the-dots.pdf (accessed on 25 January 2021).

173. Rai, P.K.; Lee, S.S.; Zhang, M.; Tsang, Y.F.; Kim, K.H. Heavy metals in food crops: Health risks, fate, mechanisms, and management. Environ. Int. 2019, 125, 365-385. [CrossRef] [PubMed] 